\title{
Dopamine-Deprived Striatal GABAergic Interneurons Burst and Generate Repetitive Gigantic IPSCs in Medium Spiny Neurons
}

\author{
Nathalie Dehorter, ${ }^{1}$ Celine Guigoni, ${ }^{2}$ Catherine Lopez, ${ }^{1}$ June Hirsch, ${ }^{1}$ Alexandre Eusebio, ${ }^{1}$ Yehezkel Ben-Ari, ${ }^{1}$ and \\ Constance Hammond ${ }^{1}$ \\ ${ }^{1}$ Institut de Neurobiologie de la Méditerranée Unité Mixte de Recherche (UMR) 901, Inserm and Aix Marseille II University, 13009 Marseille, France, and \\ ${ }^{2}$ Centre National de la Recherche Scientifique UMR 5227, Université Bordeaux 2, 33076 Bordeaux, France
}

\begin{abstract}
Striatal GABAergic microcircuits modulate cortical responses and movement execution in part by controlling the activity of medium spiny neurons (MSNs). How this is altered by chronic dopamine depletion, such as in Parkinson's disease, is not presently understood. We now report that, in dopamine-depleted slices of the striatum, MSNs generate giant spontaneous postsynaptic GABAergic currents (single or in bursts at $60 \mathrm{~Hz}$ ) interspersed with silent episodes, rather than the continuous, low-frequency GABAergic drive $(5 \mathrm{~Hz})$ observed in control MSNs. This shift was observed in one-half of the MSN population, including both " $\mathrm{D}_{1}$-negative" and " $\mathrm{D}_{1}$-positive" MSNs. Single GABA and NMDA channel recordings revealed that the resting membrane potential and reversal potential of GABA were similar in control and dopamine-depleted MSNs, and depolarizing, but not excitatory, actions of GABA were observed. Glutamatergic and cholinergic antagonists did not block the GABAergic oscillations, suggesting that they were generated by GABAergic neurons. In support of this, cell-attached recordings revealed that a subpopulation of intrastriatal GABAergic interneurons generated bursts of spikes in dopamine-deprived conditions. This subpopulation included low-threshold spike interneurons but not fast-spiking interneurons, cholinergic interneurons, or MSNs. Therefore, a population of local GABAergic interneurons shifts from tonic to oscillatory mode when dopamine deprived and gives rise to spontaneous repetitive giant GABAergic currents in one-half the MSNs. We suggest that this may in turn alter integration of cortical signals by MSNs.
\end{abstract}

\section{Introduction}

The striatum plays a central role in movement elaboration, most notably by integrating the converging glutamatergic inputs from the neocortex. The GABAergic medium spiny projection neurons (MSNs) that constitute $95 \%$ of all striatal neurons provide the only output of the striatum and are the final step of this integration process. Local GABAergic and cholinergic interneurons represent the remaining $5 \%$. The striatal network is controlled by dopaminergic synapses, whose loss in Parkinson's disease leads to major motor deficits. The manner by which dopamine controls the operation of the striatal network is not yet understood. In contrast to the extensive investigations performed on the fate of spontaneous or evoked glutamatergic currents (PSCs) in dopamine (DA)-depleted MSNs (Calabresi et al., 2007) and despite

\footnotetext{
Received March 31, 2009; revised May 6, 2009; accepted May 6, 2009.

This work was supported by Inserm, Fondation de France, and Association France Parkinson. N.D. is supported by a PhD grant from the region Provence-Alpes-Côte d'Azur and the company Neuroservice. We thank Alfonso Represa, François Michel, Christophe Porcher, and Igor Medina for their help with immunocytochemical data.

Correspondence should be addressed to Constance Hammond, Institut de Neurobiologie de la Méditerranée Unité 901, Inserm, 163 route de Luminy, BP 13, 13273 Marseille Cedex 9, France. E-mail: hammond@inmed.univ-mrs.fr.

A. Eusebio's present addresses: Department of Neurology and Movement Disorders, Centre Hospitalier Universitaire Timone, 13385 Marseille, France; and Sobell Department of Motor Neuroscience and Movement Disorders, Institute of Neurology, Queen Square, London WC1N 3BG, UK.

D0I:10.1523/JNEUROSCI.1527-09.2009

Copyright $\odot 2009$ Society for Neuroscience $\quad 0270-6474 / 09 / 297776-12 \$ 15.00 / 0$
}

the overwhelming role of GABA microcircuits in the striatum (Wilson, 2007), little is known on the alterations of GABAergic currents under these conditions.

Two types of intrastriatal GABAergic interneurons control the activity of MSNs: fast-spiking (FS) interneurons and lowthreshold spike (LTS) interneurons (Kawaguchi, 1993; Tepper and Bolam, 2004) that innervate the soma and proximal dendrites of MSNs (Kita et al., 1990; Bennett and Bolam, 1994; Kubota and Kawaguchi, 2000). They exert feedforward inhibition that prevents or delays the generation of action potentials (Plenz and Kitai, 1998; Koós and Tepper, 1999; Mallet et al., 2005; Gustafson et al., 2006). There is also a dense network of recurrent GABAergic synapses between MSNs, located on dendritic spines and shafts (Wilson and Groves, 1980). These provide lateral inhibition as a result of summation of the small amplitude IPSCs (Czubayko and Plenz, 2002; Tunstall et al., 2002; Venance et al., 2004; Tepper et al., 2008). Dopaminergic input from the substantia nigra modulates the activity of GABAergic interneurons via several presynaptic and postsynaptic dopamine receptor subtypes (Bracci et al., 2002; Momiyama, 2002; Centonze et al., 2002, 2003), as do cholinergic interneurons [the tonically active neurons (TANs)] (Zhou et al., 2002; Sullivan et al., 2008) via muscarinic and nicotinic receptors (Koós and Tepper, 2002).

Using the basal ganglia slice (BGS) (Beurrier et al., 2006) and slices of isolated striatum in which the striatum is deprived of its cortical and thalamic inputs, we now report that, in chronically 
A 1

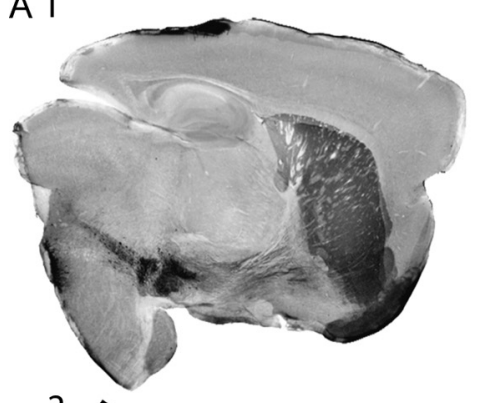

2

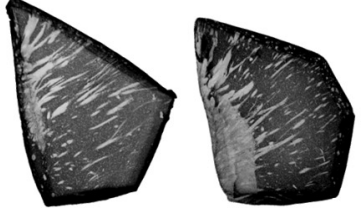

B 1

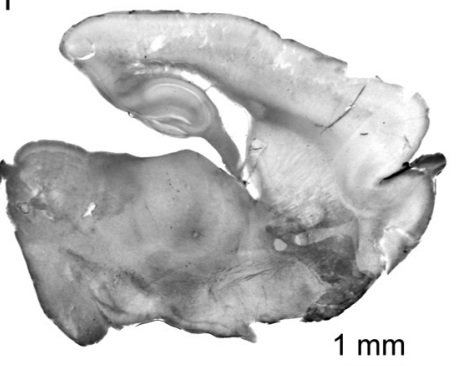

2

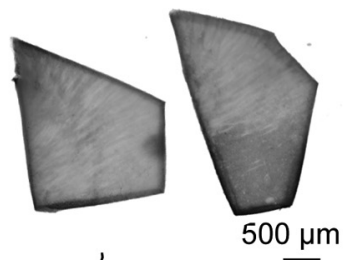

3

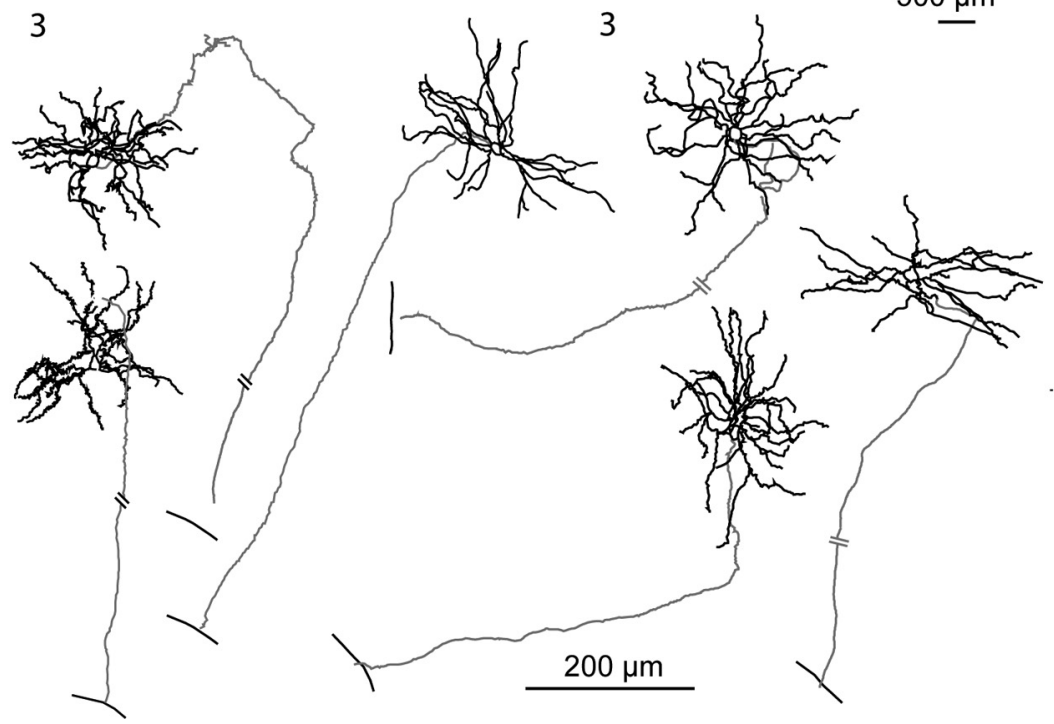

Figure 1. Extent of DA depletion in the striatum and identification of the recorded MSNs. TH immunohistochemistry of adult BGS (1) and isolated striatum (2) from control ( $\boldsymbol{A}$ ) and DA-depleted ( $\boldsymbol{B}$ ) mice. The striatum was isolated from the corresponding BGS before the recording session. Note the absence of dark TH labeling in the BGS (B1) and in the two isolated striatum (B2) from 6-OHDA-treated mice compared with the corresponding control ones $(\boldsymbol{A} 1, \boldsymbol{A} 2)$. Neurolucida reconstruction of biocytin-filled MSNs recorded in control (A3) and DA-depleted (B3) isolated striatum is shown. Somas and dendritic trees are in black and axons are in gray. The single bars crossing the axons indicate GP boundary; the double bars indicate interruption in the drawing because of the length of the axon.

DA-depleted MSNs, the continuous activity of small amplitude GABAergic sPSCs is replaced in one-half of the MSN population by giant GABAergic events separated by silent episodes. These were not affected by nicotinic or muscarinic receptor antagonists. Cell-attached recordings of single $\mathrm{GABA}_{\mathrm{A}}$ and NMDA channels from MSNs showed that this shift is not attributable to modifications of resting membrane potential $\left(V_{\text {rest }}\right)$ or of the reversal potential for GABA $\left(E_{\mathrm{GABA}}\right)$. Nor did we find alterations of the spike threshold. Giant GABAergic currents are depolarizing but do not generate spikes in either control or DA-depleted MSNs. Chronic DA depletion did not affect the activity of MSNs (silent) or cholinergic interneurons (TANs, tonically active) or GABAergic FS interneurons (tonically active or silent) recorded in the cell-attached configuration in vitro. Rather, it led to remarkable intrinsic oscillations in a subpopulation of GABAergic LTS interneurons. We propose that the ensuing powerful GABAergic barrage of giant GABA sPSCs profoundly alters the integrative functions of the striatum by interacting with cortical information traveling throughout the striatum.

\section{Materials and Methods}

Chronic lesion of the dopaminergic innervation of the striatum. We lesioned the dopaminergic innervation in one striatum of C57BL/6 mice (15-25 g) aged postnatal day 15 (P15) to P50 by local stereotaxic injection of 6-hydroxydopamine (6-OHDA) under 5\% ketamine (Imalgène 1000$) / 2.5 \%$ xylazine (Rompun $2 \%$ ) anesthesia $(10 \mu \mathrm{l} / \mathrm{g}$, i.p.). Two microinjections of 6-OHDA were performed through a NanoFIL syringe (outside diameter, $135 \mu \mathrm{m}$; WPI) placed into the left dorsal striatum at the following coordinates using a David Kopf stereotaxic apparatus: 1.0 and $1.2 \mathrm{~mm}$ rostral to bregma, 1.8 and $2.2 \mathrm{~mm}$ lateral to the midline, 2.7 and $2.8 \mathrm{~mm}$, respectively, below the surface of the skull. 6-OHDA was dissolved in saline containing $0.05 \%$ ascorbic acid, and injected at a dose of $6 \mu \mathrm{g}$ in a volume of $0.5 \mu$ l over a $5 \mathrm{~min}$ period. The syringe was left in place for $5 \mathrm{~min}$ after the end of injection. We performed in vitro recordings $15-30 \mathrm{~d}$ after the lesion. The efficacy of the 6-OHDA-induced lesion of dopaminergic terminals in the striatum was determined $2-3$ d before the recording session by apomorphine-induced rotation $(0.5 \mathrm{mg} / \mathrm{kg}$ in $0.1 \%$ ascorbic acid, i.p.; Sigma-Aldrich) (Iancu et al., 2005). Lesioned mice performed 7.0 \pm 0.3 right turns per minute and no left turn $(n=47)$. In contrast, control mice performed $0.18 \pm$ 0.07 right turns per minute and $0.23 \pm 0.06$ left turns per minute $(n=11)$. We checked the extent of the lesion after the recording session by immunohistochemical visualization of tyrosine hydroxylase (TH) in the striatum (see below, Immunocytochemistry).

Slice preparation. C57BL/6 mice (P25-P60), either control or bearing a chronic lesion of the dopaminergic fibers in the striatum, were killed by decapitation under halothane anesthesia. Oblique parasagittal slices ( $380 \mu \mathrm{m}$ thick) were cut with an angle of $10 \pm 2^{\circ}$ to obtain the BGS as previously described (Beurrier et al., 2006) (Fig. $1 \mathrm{A1}, \mathrm{B1})$. For the slicing procedure, the ice-cold oxygenated solution contained the following (in $\mathrm{mM}$ ): 110 choline, $2.5 \mathrm{KCl}, 1.25 \mathrm{NaH}_{2} \mathrm{PO}_{4}, 7$ $\mathrm{MgCl}_{2}, 0.5 \mathrm{CaCl}_{2}, 25 \mathrm{NaHCO}_{3}, 7$ glucose. To test for a possible role of choline, slices were also cut in a sucrose solution containing the following (in mM): $85 \mathrm{NaCl}, 2.5 \mathrm{KCl}, 1 \mathrm{NaH}_{2} \mathrm{PO}_{4}, 4 \mathrm{MgCl}_{2}, 1 \mathrm{CaCl}_{2}, 25$ $\mathrm{NaHCO}_{3}, 25$ glucose, 75 sucrose $(n=4)$. During the recovery period, BGSs were placed at room temperature (RT) with standard artificial CSF (ACSF) saturated with $95 \% \mathrm{O}_{2} / 5 \% \mathrm{CO}_{2}$ and containing the following (in mM): $126 \mathrm{NaCl}, 3.5 \mathrm{KCl}, 1.2 \mathrm{NaH}_{2} \mathrm{PO}_{4}, 1.3 \mathrm{MgCl}_{2}, 2 \mathrm{CaCl}_{2}, 25 \mathrm{NaHCO}_{3}$, 11 glucose. To isolate the striatum from its surrounding structures (cortex, thalamus, pallidum), we performed a knife cut along its borders under a dissecting microscope before the recording session (Fig. $1 A 2, B 2)$. These slices were prepared to study the direct effect of bathapplied drugs on the striatal network.

Electrophysiology: solutions, data acquisition, and analysis. All recordings were made at $32^{\circ} \mathrm{C}$. Cells were visualized with infrared-differential interference optics (Axioskop2; Zeiss). For whole-cell voltage-clamp recordings of postsynaptic $\mathrm{GABA}_{\mathrm{A}}$ currents, the pipette $(6-10 \mathrm{M} \Omega$ ) contained the following (in $\mathrm{mm}$ ): 120 Cs-gluconate, $13 \mathrm{CsCl}, 1 \mathrm{CaCl}_{2}, 10$ HEPES, 10 EGTA, pH 7.2-7.4 (275-285 mOsm), or $110 \mathrm{CsCl}, 30$ K-gluconate, $0.1 \mathrm{CaCl}_{2}, 10 \mathrm{HEPES}, 1.1 \mathrm{EGTA}, 4 \mathrm{MgATP}$, and $0.3 \mathrm{NaGTP}$. We used the CsGlu solution to measure spontaneous $\mathrm{GABA}_{\mathrm{A}}$ currents at the reversal potential for glutamatergic $(+10 \mathrm{mV})$ events (Cossart et al., 
2000) and the $\mathrm{CsCl}$ solution to measure the miniature $\mathrm{GABA}_{\mathrm{A}}$ currents at $V_{\mathrm{H}}=-60 \mathrm{mV}$ (in the continuous presence of $1 \mu \mathrm{M}$ TTX plus $10 \mu \mathrm{M}$ $\mathrm{CNQX}$ plus $40 \mu \mathrm{M} \mathrm{APV}$ ). For current-clamp recordings, patch electrodes contained the following (in $\mathrm{mm}$ ): $128.5 \mathrm{~K}$-gluconate, $11.5 \mathrm{KCl}, 1 \mathrm{CaCl}_{2}$, 10 EGTA, 10 HEPES, 2.5 MgATP, and 0.3 NaGTP, pH 7.32, 280 mOsm or the following (in mM): $125 \mathrm{KMeSO}_{4}, 15 \mathrm{KCl}, 5 \mathrm{NaCl}, 10$ HEPES, 2.5 Mg-ATP, $0.3 \mathrm{Na}-\mathrm{GTP}$. The CsGlu, $\mathrm{CsCl}$, and $\mathrm{KGlu}$ pipette solutions gave a reversal potential for chloride close to $-58,-5$, and $-63 \mathrm{mV}$ at $35^{\circ} \mathrm{C}$, respectively. Biocytin (Sigma-Aldrich; $5 \mathrm{mg} / \mathrm{ml}$ ) was added in all pipette solutions and osmolarity corrected when necessary. We performed patch-clamp recordings in whole-cell or cell-attached configuration using the Digidata 1344A interface, the Multiclamp 700A amplifier, and pClamp8 software (Molecular Devices). Spontaneous and miniature $\mathrm{GABA}_{\mathrm{A}}$ receptor-mediated PSCs (sPSCs and mPSCs) were recorded at a holding potential of +10 and $-60 \mathrm{mV}$, respectively. Currents were stored on pClamp8 (Molecular Devices) and analyzed off-line with Mini Analysis program (Synaptosoft 6.0), Clampfit 9.2, Origin 5.0, and Autosignal 1.7 to determine the frequency and amplitude of GABAergic synaptic events. All detected currents were then visually inspected to reject artifactual events. To generate the averaged GABA $\mathrm{A}_{\mathrm{A}}$ mPCs, multiple overlapping events were first discarded, and the remaining events were aligned on their rising phase. Only MSNs that exhibited a stable pattern of $\mathrm{GABA}_{\mathrm{A}}$ mPSCs during 20-30 min were taken into account. The histogram and cumulative distributions were constructed using $\mathrm{GABA}_{\mathrm{A}}$ mPSCs recorded over $3 \mathrm{~min}$. In the sPSC recordings, we defined as "giant" any sPSC with an amplitude $>200 \mathrm{pA}$ and as "burst" a minimum of five sPSCs associated with a baseline elevation. More than five giant events and three bursts were required during the 3 min analysis for the pattern to be deemed "oscillatory."

For cell-attached recordings of single $\mathrm{GABA}_{\mathrm{A}}$ channels, the pipette (4-5 M $\Omega$ ) contained the following (in mM): $120 \mathrm{NaCl}, 20$ TEA-Cl (tetraethylammonium chloride), $5 \mathrm{KCl}, 54$-aminopyridine, $0.1 \mathrm{CaCl}_{2}, 10$ $\mathrm{MgCl}_{2}, 10$ glucose, 10 HEPES-NaOH buffered to $\mathrm{pH} 7.2-7.3$, osmolality of 300-320 mosmol. GABA ( $5 \mu \mathrm{M})$ was included in the above pipette saline together with isoguvacine $(5 \mu \mathrm{M})$ and $\mathrm{CsCl}(3 \mu \mathrm{M})$ to optimize channel openings (because of the negative charge of GABA, positive currents may repulse GABA far from the membrane; under these conditions, isoguvacine may thus replace it). For single NMDA channels, pipettes were filled with nominally magnesium-free ACSF containing the following (in mM): $140 \mathrm{NaCl}, 3.5 \mathrm{KCl}, 1.8 \mathrm{CaCl}_{2}, 10 \mathrm{HEPES}$, buffered to $\mathrm{pH} 7.43$, osmolality of $300-320$ mosmol. NMDA $(10 \mu \mathrm{M})$ and glycine (10 $\mu \mathrm{M})$ were included in the above saline to optimize channel openings and strychnine $(1 \mu \mathrm{M})$ to block glycinergic receptors. For cell-attached recordings of neuronal activity, pipettes (4-5 M $\Omega$ ) contained $150 \mathrm{~mm}$ $\mathrm{NaCl}$. To identify the morphology of neurons recorded in cell-attached configuration, we repatched them with a conventional whole-cell electrode containing biocytin (see above). The single-channel currents were filtered at $1 \mathrm{kHz}\left(\mathrm{GABA}_{\mathrm{A}}\right.$ channels) or $3 \mathrm{kHz}$ (NMDA channels) and digitized at $10 \mathrm{kHz}$. Multilevel and short $(<2 \mathrm{~ms})$ openings were discarded during analysis. $I-V$ relationships were performed by measuring amplitude of unitary GABA and NMDA currents evoked by steps from -120 to $+40 \mathrm{mV}$. Histograms of cursor-measured amplitudes allowed determination of the mean unitary current amplitude at each voltage tested. Series resistance $\left(R_{\mathrm{s}}\right)$, membrane capacitance $\left(C_{\mathrm{m}}\right)$, and input resistance $\left(R_{\text {input }}\right)$ were determined by on-line fitting analysis of the transient currents in response to a $-5 / 10 \mathrm{mV}$ pulse. Criteria for considering a recording included $R_{\text {input }}>100 \mathrm{M} \Omega, R_{\mathrm{s}}<25 \mathrm{M} \Omega$, with $\Delta R_{\mathrm{s}}<30 \%$ change. Average values are presented as means \pm SEM and statistical comparisons were performed with the Student's $t$ test (SigmaStat 3.1, Origin 5.0) or Mann-Whitney rank sum test (SigmaStat 3.1). The level of significance was set as $p<0.05$.

We performed extracellular unit recording of striatal neurons with either conventional extracellular tungsten electrodes or with the multielectrode array (MEA) technology (Heuschkel et al., 2002; Steidl et al., 2006). The MEA setup (Multi Channel Systems) is composed of a 60 channel amplifier head stage connected to a 60 channel A/D card. The slice is gently positioned on the array of 60 platinum electrodes (spaced by $100 \mu \mathrm{m}$ ) used as recording electrodes (Ayanda Biosystems). Record- ings were acquired and analyzed with the MC Rack software commercially available from Multi Channel Systems.

Measurements of $\mathrm{V}_{\text {rest }}, \mathrm{E}_{G A B A_{A}}, \mathrm{~V}_{\text {threshold. }}$ To determine the action of GABA in a given neuron (depolarizing or hyperpolarizing), one must measure the reversal potential of the $\mathrm{GABA}_{\mathrm{A}}$-mediated current $\left(E_{\mathrm{GABA}_{\mathrm{A}}}\right)$ and the resting membrane potential $\left(V_{\text {rest }}\right)$. However, conventional whole-cell recordings introduce a number of errors in these measures. We therefore estimated the value of $V_{\text {rest }}$ from cell-attached recordings of the single-channel NMDA current $\left(i_{\mathrm{NMDA}}\right)$, which is known to reverse at a membrane potential $\left(V_{\mathrm{m}}\right)$ close to $0 \mathrm{mV}$ (Nowak et al., 1984) (see Discussion). We plotted the relationship between $i_{\mathrm{NMDA}}$ and the extracellular potential applied to the patch of membrane $\left(V_{\mathrm{p}}\right)$ from experimental data (see Fig. $5 A$ ). This curve $\left[i_{\mathrm{NMDA}}=f\left(V_{\mathrm{p}}\right)\right]$ gives the value of $V_{\mathrm{p}}$ when $i_{\mathrm{NMDA}}=0 \mathrm{pA}$. At this value of $V_{\mathrm{p}}$, single-channel NMDA current is null because $V_{\mathrm{m}}=V_{\mathrm{p}}-V_{\text {rest }}=0 \mathrm{mV}$. This allows estimation of $V_{\text {rest }}\left(V_{\text {rest }}=V_{\mathrm{p}}\right)$. To estimate $\left(E_{\mathrm{GABA}_{\mathrm{A}}}\right)$, we plotted the relationship between the single-channel GABA $A_{A}$ current $\left(i_{\mathrm{GABA}_{\mathrm{A}}}\right)$ and $V_{\mathrm{p}}$. This curve $\left[i_{\mathrm{GABA}(\mathrm{A}}=f\left(V_{\mathrm{p}}\right)\right]$ gives the value of $V_{\mathrm{p}}$ when $i_{\mathrm{GABA}_{\mathrm{A}}}=0 \mathrm{pA}$ (see Fig. $5 B$ ), because by definition when $i_{\mathrm{GABA}_{\mathrm{A}}}$ is null, $V_{\mathrm{m}}=E_{\mathrm{GABA}_{\mathrm{A}}}$. Therefore, when $i_{\mathrm{GABA}_{\mathrm{A}}}=0 \mathrm{pA}, V_{\mathrm{m}}=V_{\mathrm{p}}-V_{\text {rest }}=E_{\mathrm{GABA}_{\mathrm{A}}}$ (i.e., $E_{\mathrm{GABA}_{\mathrm{A}}}-V_{\text {rest }}=-V_{\mathrm{p}}$ ). By definition, $E_{\mathrm{GABA}_{\mathrm{A}}}-V_{\text {rest }}=\mathrm{DF}_{\mathrm{GABA}_{\mathrm{A}}}$, the driving force of chloride ions through the $\mathrm{GABA}_{\mathrm{A}}$ channel (Tyzio et al., 2003). Therefore, when $i_{\mathrm{GABA}_{\mathrm{A}}}=0 \mathrm{pA}, \mathrm{DF}_{\mathrm{GABA}_{\mathrm{A}}}=-V_{\mathrm{p}}$. Knowing $V_{\text {rest }}$ and $\mathrm{DF}_{\mathrm{GABA}_{\mathrm{A}}}$, it is easy to calculate $E_{\mathrm{GABA}_{\mathrm{A}}}=\mathrm{DF}_{\mathrm{GABA}_{\mathrm{A}}}+V_{\text {rest }}$. In addition, the slopes of the $i_{\mathrm{N}^{-}}$ $\mathrm{MDA}-V_{\mathrm{p}}$ and $i_{\mathrm{GABA}_{\mathrm{A}}}-V_{\mathrm{p}}$ relationships provide an estimate of the conductance of NMDA and GABA channels, respectively. The threshold potential for $\mathrm{Na}^{+}$spikes $\left(V_{\text {threshold }}\right)$ was estimated in whole-cell currentclamp recordings by applying successive depolarizing steps [duration, 250 or $950 \mathrm{~ms}$ (Centonze et al., 2003)] or by evoking spikes by cortical stimulation, both from the value of $V_{\text {rest }}$ calculated above.

Identification of recorded striatal neurons. We identified MSNs during recording based on their typical rectification during hyperpolarizing steps and their firing delay in response to depolarizing steps (see Fig. $5 C$ ). They had a round dendritic field with extremely spiny dendrites and axons that extended outside the striatum toward the globus pallidus (Fig. $1 A 3, B 3)$. Cholinergic interneurons were readily identified in the slice by their large somata and thick primary dendrites. Negative-current pulses produced an initial hyperpolarization followed by a depolarizing sag in the membrane potential. Depolarizing pulses resulted in nonadapting, regular spiking. Examination of biocytin-filled neurons confirmed the above morphological criteria (see Fig. $6 B$ ). FS interneurons discharged in trains of narrow action potentials. Epochs of firing were interspersed with periods of silence during depolarizing steps just above threshold. Their aspiny dendrites branched modestly (see Fig. 7A). In addition to fast spikes, LTS interneurons also displayed low-threshold spikes when depolarized from potentials near $-70 \mathrm{mV}$ or after cessation of hyperpolarized pulses (see Fig. $7 B$ ). They had a high input resistance compared with the other neuronal types $(\sim 600 \mathrm{M} \Omega)$. Their dendrites radiated a long distance and were infrequently branched (Kawaguchi, 1993; Tepper and Bolam, 2004).

Drugs. Drugs were prepared as concentrated stock solutions and diluted in ACSF for bath application: bicuculline, a $\mathrm{GABA}_{\mathrm{A}}$ receptor antagonist; carbachol, a cholinergic agonist; muscarine, a muscarinic cholinergic agonist; nicotine, a nicotinic cholinergic agonist; mecamylamine, a nicotinic antagonist; scopolamine, a muscarinic antagonist; D-APV, a NMDA receptor antagonist; 6-cyano-7-nitroquinoxaline 2,3-dione (CNQX), an AMPAkainate receptor antagonist; tetrodotoxin (TTX), a $\mathrm{Na}^{+}$channel blocker; $R(+)$-7-chloro-8-hydroxy-3-methyl-1-phenyl-2,3,4,5-tetrahydro- $1 \mathrm{H}$-3benzazepine hydrochloride (SCH23390), a $\mathrm{D}_{1}$-like receptor antagonist; and sulpiride, a $\mathrm{D}_{2}$ receptor antagonist. All drugs were purchased from Sigma-Aldrich.

Immunocytochemistry. To visualize the lesion of dopaminergic axons in the striatum, we performed immunocytochemistry of TH in the recorded slices, or those just medial or lateral to those recorded. After $12 \mathrm{~h}$ in paraformaldehyde $(3 \%)$ at $4^{\circ} \mathrm{C}$, the sections were rinsed in PBS and pretreated with $30 \% \mathrm{H}_{2} \mathrm{O}_{2}(30 \mathrm{~min})$ and blocked by $2 \%$ normal goat serum (NGS) in PBS containing 0.3\% Triton X-100 for $30 \mathrm{~min}$, and then incubated for $12 \mathrm{~h}$ with anti-TH polyclonal antibody (Pel-Freez) at a dilution of 1:1000. After rinsing with PBS, they were incubated for $1.5 \mathrm{~h}$ 
with anti-mouse IgG secondary antibody (Tebu) at a dilution of 1:300 in PBS plus 2\% normal goat serum. Sections were washed with PBS and incubated for $1.5 \mathrm{~h}$ in ABC complex at a dilution of 1: 500 (Euromedex). They were rinsed and incubated for $\sim 10 \mathrm{~min}$ in 3,3'-diaminobenzidine (DAB) $(0.7 \mathrm{mg} / \mathrm{ml})$ with peroxide $(0.2 \mathrm{mg} / \mathrm{ml})$ (SigmaFast), rinsed, mounted in Crystal/Mount (Electron Microscopy Sciences), coverslipped, and examined with a conventional microscope. Electrophysiological data were taken into account only when a severe loss (>90\%) of tyrosine hydroxylase immunoreactivity was present in the dorsomedial striatum in which recordings were performed (Fig. 1 B1,B2). To visualize the recorded cells in the striatum and identify them, we revealed the biocytin injected during whole-cell recordings. After $12 \mathrm{~h}$ in paraformaldehyde $(3 \%)$ at $4^{\circ} \mathrm{C}$, the sections were rinsed in PBS, left $12 \mathrm{~h}$ in $20 \%$ sucrose in phosphate buffer ( $\mathrm{PB})$, and left at $-80^{\circ} \mathrm{C}$ for at least $2 \mathrm{~h}$. They were thawed at room temperature, rinsed in $\mathrm{PB}$, and incubated $30 \mathrm{~min}$ in $1 \% \mathrm{H}_{2} \mathrm{O}_{2}$ in $\mathrm{PB}$. Sections were washed with $\mathrm{PB}$ and $\mathrm{KPBS}$ and incubated for $12 \mathrm{~h}$ in $\mathrm{ABC}$ complex at a dilution of 1:100 in KPBS plus 0.3\% Triton (Abcys). They were rinsed in KPBS and incubated for $\sim 10 \mathrm{~min}$ in DAB $(0.7 \mathrm{mg} / \mathrm{ml})$ with peroxide $(0.2 \mathrm{mg} / \mathrm{ml})$ (SigmaFast), rinsed, mounted in Crystal/Mount (Electron Microscopy Sciences), coverslipped, and examined. Dendritic and axonal arbors were reconstructed for morphological analysis using the Neurolucida system (MicroBrightField).

To identify the $\mathrm{D}_{1}$ phenotype of the MSNs recorded, $\mathrm{D}_{1}$ R was detected by immunohistochemistry using a monoclonal antibody raised in rat against a 97 aa sequence corresponding to the $\mathrm{C}$ terminus of the human $\mathrm{D}_{1} \mathrm{R}$ (Sigma-Aldrich) (Levey et al., 1993; Guigoni et al., 2007). Slices were cryoprotected in PBS with 25\% saccharose, freeze-thawed in isopentane, and rinsed in PBS. Slices were then incubated in 4\% NGS for $30 \mathrm{~min}$ and then in $\mathrm{D}_{1} \mathrm{R}$ antibody (1:1000) supplemented with $1 \%$ NGS overnight at RT. After thorough rinsing, slices were incubated for 90 min at RT in Alexa 568 goat anti-rat (1:200 in PBS; Invitrogen) with streptavidin coupled with DTAF (dichlorotriazinylamino-fluorescein) (1:200; FluoProbes; Interchim) to detect biocytin injected in the recorded neurons. After thorough rinsing, slices were again incubated in $\mathrm{D}_{1} \mathrm{R}$ antibody for $60 \mathrm{~min}$, rinsed again, and incubated with secondary antibody for $60 \mathrm{~min}$. This step was repeated once more. After thorough rinsing, slices were mounted in Vectashield (Vector Laboratories/Biovalley), coverslipped, and examined with a confocal microscope (Zeiss LSM 510).

\section{Results}

Spontaneous $\mathrm{GABA}_{\mathrm{A}}$ currents increase in amplitude and shift to oscillatory mode in DA-depleted MSNs

We have recorded the activity of 97 control and 98 DA-depleted MSNs in slices of isolated striatum that have been disconnected from their glutamatergic afferent neurons (cortical and thalamic) and of 10 control and 18 DA-depleted MSNs in BGS. In wholecell or cell-attached configuration (current-clamp mode), all the recorded MSNs were silent at resting membrane potential in both the control and DA-depleted states. The pattern of GABA $\mathrm{A}_{\mathrm{A}} \mathrm{sPCs}$ in identified MSNs $(n=40)$ was mainly tonic, with lowfrequency $(4.5 \pm 0.4 \mathrm{~Hz})$ and low-amplitude $(34.1 \pm 1.8 \mathrm{pA})$ events in isolated striatum (Fig. $2 \mathrm{~A}$ ). The overall mean current density of this tonic pattern was $459 \pm 40 \mathrm{nA} \cdot \mathrm{ms}$ (Fig. $2 C$, top). In 10 of the $40 \mathrm{MSNs}$, we also observed rare giant $(>200 \mathrm{pA})$ currents (mean amplitude, $306 \pm 8 \mathrm{pA}$; range, 200-650 pA; mean frequency, $0.14 \pm 0.03 \mathrm{~Hz}$ ) or rare bursts (mean intraburst frequency, $29.3 \pm 1.1 \mathrm{~Hz}$; mean intraburst amplitude, $51.3 \pm 1.0$ $\mathrm{pA} ; n=3$ of 40 ) (Figs. $2 \mathrm{~A}$, middle and bottom traces; $C$, top; $3 A$, control). The results obtained in BGS were totally similar as those from isolated striatum $(5.6 \pm 1.0 \mathrm{~Hz}, p=0.31 ; 30.0 \pm 4.3 \mathrm{pA}, p=$ $0.44)$.

After chronic DA depletion, a new pattern emerged, characterized by a higher current density $(1311 \pm 142 \mathrm{nA} \cdot \mathrm{ms})$ and the higher occurrence of giant $\mathrm{GABA}_{\mathrm{A}}$ sPSCs such as (1) single sPSCs of higher amplitude ( $340 \pm 6 \mathrm{pA}$; range, $240-1900 \mathrm{pA} ; p<0.01$ ) and frequency $(0.29 \pm 0.07 \mathrm{~Hz} ; p<0.05)$ compared with control and (2) bursts of sPSCs, which recurred at regular intervals of $6.0 \pm 0.8 \mathrm{~s}$ during periods varying from 6 to $1650 \mathrm{~s}$ (Fig. 2 B1,C). The mean intraburst frequency of sPCSs $(58.7 \pm 1.3 \mathrm{~Hz})$ and amplitude $(95.9 \pm 2.6 \mathrm{pA})$ both doubled compared with control ( $p<0.001$ for both) (Fig. 3A, DA-depleted). This new giant and oscillatory pattern was observed in $45 \%$ of the recorded MSNs ( $n=20$ of 45$)$. In the remaining $55 \%$ MSNs $(n=25$ of 45$)$, the pattern of afferent $\mathrm{GABA}_{\mathrm{A}} \mathrm{sPSC}$ was relatively unchanged by the DA lesion. The mean current density, frequency, and amplitude of sPSCs was not statistically different from control $(496 \pm 59$ $\mathrm{nA} \cdot \mathrm{ms}, p=0.35 ; 5.6 \pm 0.6 \mathrm{~Hz}, p=0.11 ; 35.3 \pm 2.0 \mathrm{pA}, p=0.67$; $n=25$ ) (Fig. $2 B 2 ; C$, top). The results obtained in DA-depleted BGS were similar as those recorded in isolated DA-depleted striatum with the presence of the oscillatory pattern of PSCs in $45 \%$ of MSNs (intraburst frequency, $73.3 \pm 3.1 \mathrm{~Hz}$, and intraburst amplitude, $111.4 \pm 4.2 \mathrm{pA}$; giants amplitude, $270 \pm 39 \mathrm{pA} ; n=8$ of 18 ) and of the regular pattern in the remaining $55 \%$. In conclusion, spontaneous $\mathrm{GABA}_{\mathrm{A}}$ sPSCs became strikingly oscillatory in $\sim 50 \%$ of the MSNs in chronically DA-depleted striatum independently of the presence of corticostriatal neurons. We never observed such a pattern in control conditions.

The oscillatory pattern of $\mathrm{GABA}_{\mathrm{A}}$ sPSCs did not depend on the internal pipette solution, holding membrane potential, or spontaneous glutamate synaptic activity. This pattern was observed with a recording solution with low internal chloride (CsGlu-filled electrodes) from $V_{\mathrm{H}}=-75$ to $+10 \mathrm{mV}$ (Fig. $3 B$ ) or with high internal chloride (CsCl-filled electrode) (data not shown) and in the absence or presence of CNQX (10-30 $\mu \mathrm{M})$ and APV $(40 \mu \mathrm{M})$ (Fig. 3C). As expected, bicuculline $(10 \mu \mathrm{M})$, an antagonist of $\mathrm{GABA}_{\mathrm{A}}$ receptors, suppressed all sPSCs (Fig. $3 C$ ). To test whether the oscillatory pattern resulted from chronic or acute dopamine depletion, we acutely blocked dopaminergic transmission in control slices by simultaneously applying $\mathrm{D}_{1} \mathrm{R}$ and $\mathrm{D}_{2} \mathrm{R}$ antagonists ( $\mathrm{SCH} 23390,10 \mu \mathrm{M}$; sulpiride, $10 \mu \mathrm{M}$ ). Acute blockade did not mimic chronic DA depletion. This treatment did not cause sPSCs to become oscillatory, nor did it significantly affect their frequency (from $6.6 \pm 1.0$ to $5.5 \pm 1.5 \mathrm{~Hz} ; p=0.91$ ) or amplitude (from $29.6 \pm 1.6$ to $24.8 \pm 3.5 ; p=0.45$ ) (data not shown) $(n=7)$. This strongly suggested that the oscillatory pattern of $\mathrm{GABA}_{\mathrm{A}}$ sPSCs resulted from the chronic, rather than acute, absence of dopaminergic terminals.

To understand whether giant currents had a postsynaptic or a presynaptic origin, we recorded miniature $\mathrm{GABA}_{\mathrm{A}}$ currents. Their mean frequency and mean amplitude were not significantly different between control and DA-depleted MSNs that displayed the oscillatory pattern (frequency: $1.5 \pm 0.2 \mathrm{~Hz}, n=15$, vs $1.8 \pm 0.5 \mathrm{~Hz}, n=7$, $p=0.5$; amplitude: $31.9 \pm 1.5 \mathrm{pA}, n=15$, vs $32.7 \pm 2.8, n=7, p=$ $0.8)$, suggesting that the oscillatory pattern has a presynaptic origin (supplemental Fig. 1, available at www.jneurosci.org as supplemental material).

\section{$D_{1}$-positive and $D_{1}$-negative MSNs generate the oscillatory pattern}

Since MSNs are composed of $\mathrm{D}_{2}$ striatopallidal and $\mathrm{D}_{1}$ striatonigral subtypes, with a relatively selective distribution of $D_{1}$ and $\mathrm{D}_{2}$ dopamine receptors that are not altered by chronic dopamine depletion (Nadjar et al., 2006), we reasoned that the two types of $\mathrm{GABA}_{\mathrm{A}}$ sPSCs patterns recorded could correspond to these two types of MSNs. To test this hypothesis, we performed immunocytochemical labeling of intracellularly injected biocytin with $\mathrm{D}_{1}$ dopamine receptor antibodies (see Materials and Methods). Of the 30 double-labeled MSNs recorded in DA-depleted striatum, 13 generated the oscillatory 
A
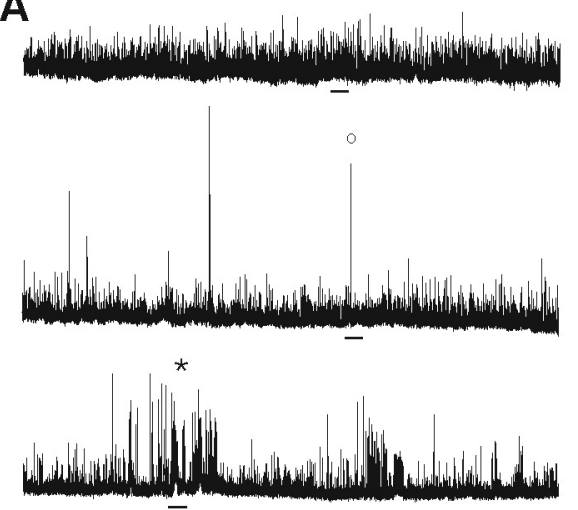

B 。
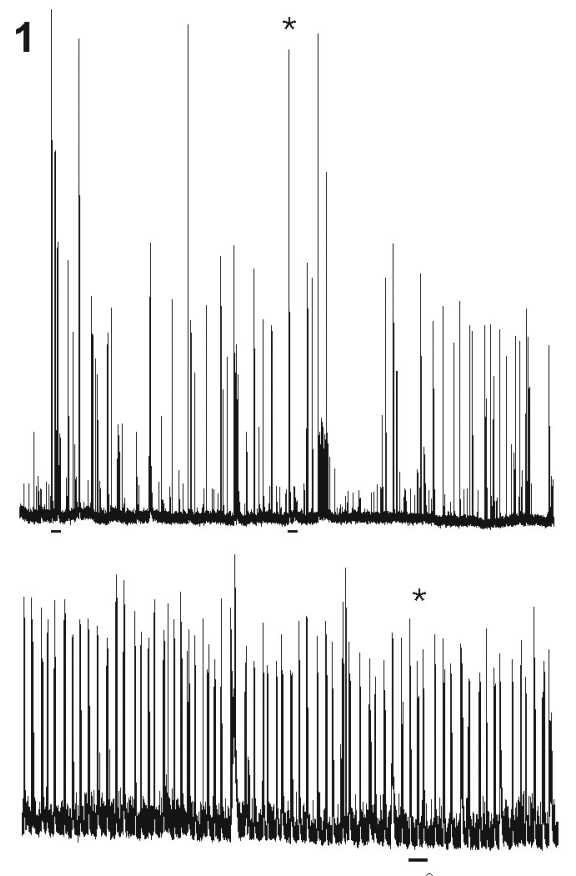

-

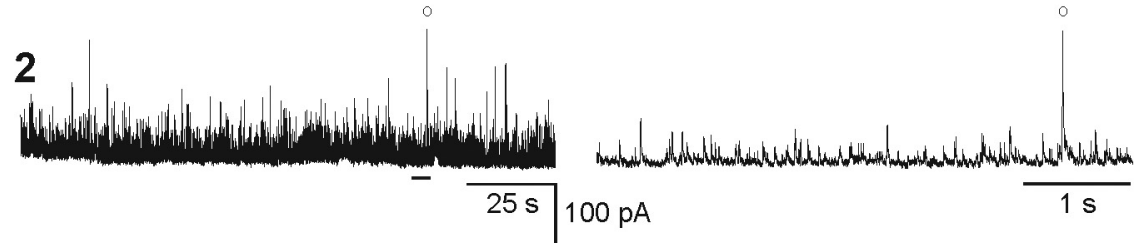

C
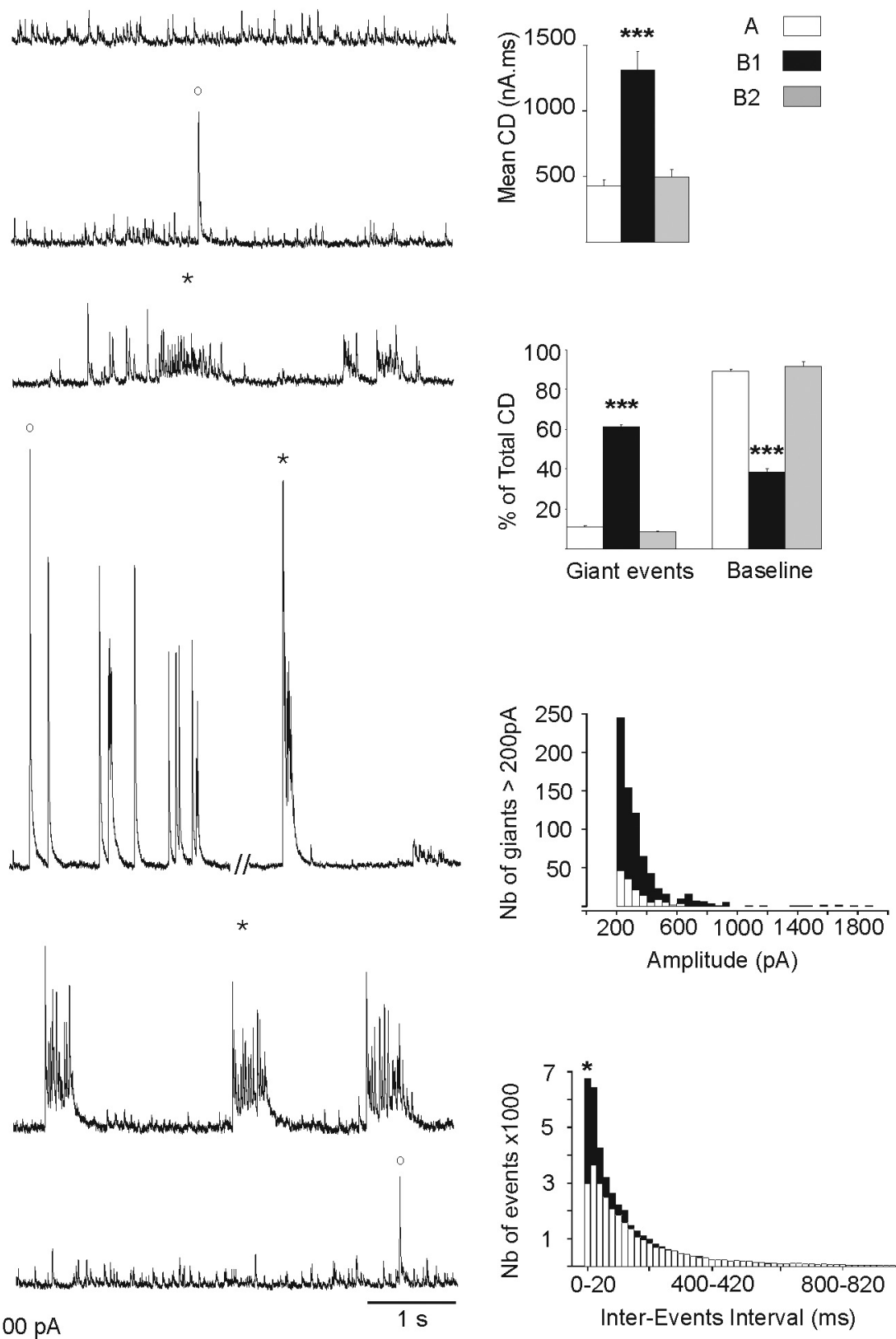

Figure 2. Spontaneous $\mathrm{GABA}_{A}$ currents recorded in MSNs before and after chronic DA depletion. Voltage-clamp recordings of $\mathrm{GABA}_{A} \mathrm{SPSCs}$ with CsGlu-filled electrodes $\left(V_{H}=+10 \mathrm{mV}\right)$. $A$, Tonic pattern of $\mathrm{GABA}_{\mathrm{A}} \mathrm{SPSC}$ in control isolated striatum (68\% of MSNs; top traces) with the rare presence of single sPSCs $>200 \mathrm{pA}\left({ }^{\circ}\right)(23 \%$ of MSNs; middle traces) and bursts of $\mathrm{SPSC}$ $(*)\left(9 \%\right.$ of MSNs; bottom traces). $B$, The two patterns of $\mathrm{ABBA}_{A}$ SPSCs recorded from DA-depleted isolated striatum. B1, Oscillatory pattern observed in $45 \%$ of the MSNs and characterized by the frequent presence of giant events: single SPSCS $\left(^{\circ}\right)$ and bursts of SPSCS $\left(^{*}\right)$. B2, Tonic pattern in the remaining MSNs $(55 \%)$. The calibration bars are the same for all recordings in $\boldsymbol{A}$ and $\boldsymbol{B}$. C (from top to bottom), Quantification of the data from control MSNs as shown in $\boldsymbol{A}$ (white) and from DA-depleted MSNs as shown in $\boldsymbol{B} \boldsymbol{1}$ (black) or $\boldsymbol{B} \boldsymbol{2}$ (gray). The mean current density (CD) of GABA $A_{A}$ sPSCs increased threefold between $\boldsymbol{A}$ and $\boldsymbol{B} \mathbf{1}$ or $\boldsymbol{B} \mathbf{2}$ and $\boldsymbol{B} 1$. Giant events represented 11 and $8 \%$ of the total $C D$ in $\boldsymbol{A}$ and $\boldsymbol{B 2}$, respectively, but $61 \%$ in $\boldsymbol{B}$. The baseline events ( $\angle 200 \mathrm{pA}$ ) represented 89 and $92 \%$ of the total $C D$ in $\boldsymbol{A}$ and $\boldsymbol{B} 2$, respectively, but $38 \%$ in $\boldsymbol{B}$. The distribution of single giant sPSCs $>200 \mathrm{pA}$ shows the increased number of these events and the presence of very large amplitude events $(1000-1800 \mathrm{pA})$ in $\boldsymbol{B} \mathbf{1}$ compared with $\boldsymbol{A}$. Interevent intervals were shorter in $\boldsymbol{B} \boldsymbol{1}$ than in $\boldsymbol{A}$ as most of the events were present in the interval $0-20 \mathrm{~ms}$. Error bars indicate SEM. ${ }^{*} p<0.05 ;{ }^{* * *} p<0.001$.

$\mathrm{GABA}_{\mathrm{A}}$ pattern and 17 the tonic one. Among the $13 \mathrm{MSNs}$ with the oscillatory pattern, 6 MSNs expressed $\mathrm{D}_{1}$ dopamine receptors and 7 MSNs did not (Fig. 4). Among the 17 MSNs with a tonic $\mathrm{GABA}_{\mathrm{A}}$ pattern, 4 MSNs expressed $\mathrm{D}_{1}$ receptors and 13 MSNs did not. Therefore, both " $\mathrm{D}_{1}$ positive" and " $\mathrm{D}_{1}$ negative" MSNs can generate the oscillatory $\mathrm{GABA}_{\mathrm{A}}$ pattern when dopamine deprived.
$V_{\text {rest }}, E_{\mathrm{GABA}}$, and $V_{\text {threshold }}$ of MSNs are identical in control and DA-depleted striatum

Alterations of intrinsic parameters or the polarity of GABAergic synapses could also underlie the shift in the firing pattern of MSNs. Indeed, GABA signals in neuronal disorders have been reported to shift from inhibition to excitation (Cohen et al., 2002). To determine whether dopamine depletion leads to simi- 
A Control

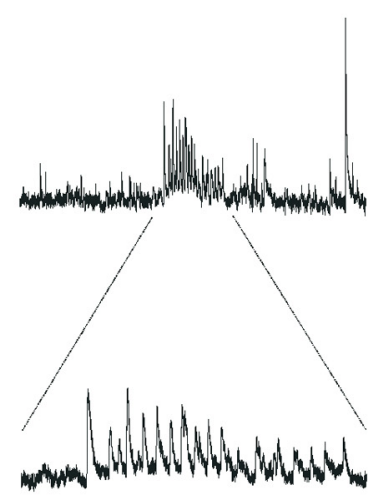

Freq $(\mathrm{Hz})$

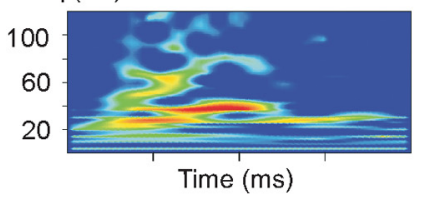

B
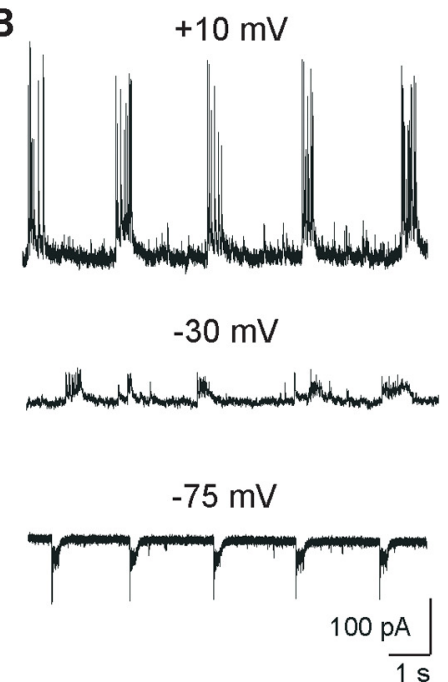
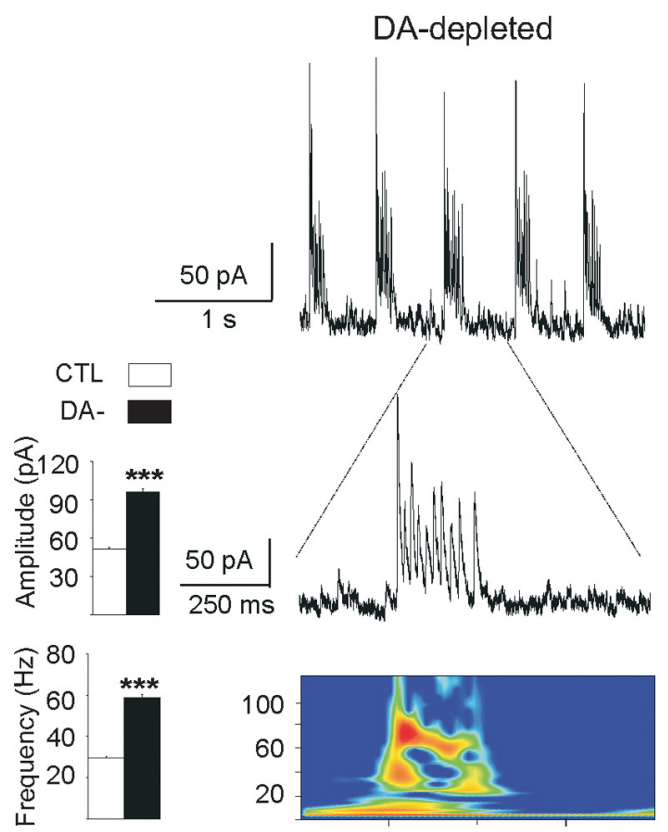

C

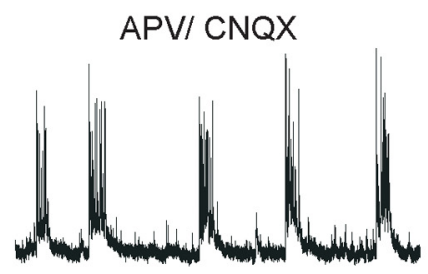

+ bicuculline

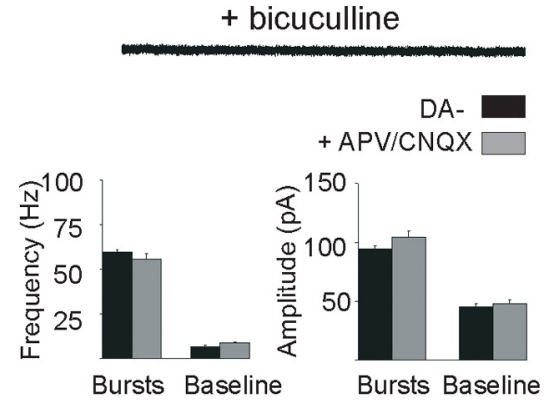

Figure 3. Burst characteristics. $\boldsymbol{A}$, Whole-cell recordings $\left(V_{H}=+10 \mathrm{mV}\right)$ of rare bursts $(\boldsymbol{A})$ and recurrent bursts $(\boldsymbol{B})$ of $G A B A_{A} S P S C S$ in control (left) and DA-depleted (right) MSNs and corresponding power spectrum analysis of a single burst. Intraburst frequency of GABA ${ }_{A} S P S C s$ are visualized by time-frequency representations (bottom colored diagrams) that enables determining the implication of different frequency ranges within the burst. The field power is here coded in colors so that red corresponds to higher amplitudes. The calibrations are identical for the left and right traces. Histograms in the center, Mean intraburst amplitude and frequency of $\mathrm{GABA}_{A}$ SPSCs in control MSNs ( $\square$ ) and in DA-depleted MSNs with an oscillatory pattern ( $\square$ ). $\boldsymbol{B}$, Recordings of recurrent bursts in a DA-depleted MSN at the indicated holding potentials (whole-cell configuration, internal CSGlu). C, Application of APV (40 $\mu \mathrm{M})$ plus CNQX (10 $\mu \mathrm{M})$ at $V_{\mathrm{H}}=+10 \mathrm{mV}$ did not significantly affect the frequency and amplitude of bursts or baseline events (bottom histograms), whereas bicuculline at $20 \mu \mathrm{m}$ totally abolished them. Error bars indicate SEM. ${ }^{* * *} p<0.001$.

lar alterations, we performed single NMDA and GABA channel recordings to determine $V_{\text {rest }}$ and $E_{\mathrm{GABA}}$, respectively. We also measured the threshold for spike generation $\left(V_{\text {threshold }}\right)$ (see Materials and Methods). Each tested neuron was successively patched in cell-attached configuration to record NMDA or $\mathrm{GABA}_{\mathrm{A}}$ single-channel currents and then in whole-cell configuration to test the $I-V$ relationship and label them with biocytin to confirm their identity as MSNs.

Current-voltage relationships of single NMDA channel currents from identified MSNs in control striatum yielded a mean resting membrane potential of $V_{\text {rest }}=-79.7 \pm 1.0 \mathrm{mV}(n=9)$

(mean NMDA conductance, $79 \pm 3 \mathrm{pS}$; $n=9$ ) (Fig. $5 A$ ). The extracellular $\mathrm{Ca}^{2+}$ concentration $(1.8 \mathrm{~mm})$ and the recording temperature $\left(32^{\circ} \mathrm{C}\right)$ may explain this large conductance compared with the typical value obtained from cell-attached recordings in central neurons (50-60 pS) (Clark et al., 1997). Current-voltage relationships of single $\mathrm{GABA}_{\mathrm{A}}$ channel currents recorded in identified MSNs yielded a mean driving force of $\mathrm{DF}_{\mathrm{GABA}}=16.1 \pm 1.9 \mathrm{mV}$ $(n=11)$ (Fig. $5 B)$, suggesting a mean reversal potential of $\mathrm{GABA}_{\mathrm{A}}$ currents of $E_{\mathrm{GA}^{-}}$ $\mathrm{BA}=-63.6 \pm 2.9 \mathrm{mV}$ (conductance, $14.9 \pm 1.1 \mathrm{pS} ; n=11)$. The threshold potential for $\mathrm{Na}^{+}$spikes in response to 250 ms depolarizing steps (Fig. $5 C$, control) was $V_{\text {threshold }}=-35.7 \pm 1.4(n=22)$. The threshold of spikes evoked in response to cortical stimulation in control MSNs was $V_{\text {threshold }}=-38.3 \pm 0.6 \mathrm{mV}(n=7)$ (Fig. $5 C$, control). $V_{\text {threshold }}$ obtained with these two methods were not statistically different $(p=0.18)$.

In DA-depleted striatum, the results obtained with the same methods were not statistically different from control: $V_{\text {rest }}=$ $-80.1 \pm 1.0 \mathrm{mV}(n=7 ; p=0.8)$ (Fig. $5 \mathrm{~A}$, right $), \mathrm{DF}_{\mathrm{GABA}_{\mathrm{A}}}=17.1 \pm 1.6 \mathrm{mV}(n=10$; $p=0.7$ ) (Fig. $5 B$, right), $E_{\mathrm{GABA}_{\mathrm{A}}}=$ $-63.0 \pm 2.9 \mathrm{mV}(n=10)$, and $V_{\text {threshold }}=$ $-35.0 \pm 0.9(n=36 ; p=0.6)$ or $-40.8 \pm$ $1.0 \mathrm{mV}$ for cortical stimulation evoked spikes $(n=8 ; p=0.06)$ (Fig. $5 C$, right). Pressure-applied isoguvacine $(100 \mu \mathrm{M}$; $100 \mathrm{~ms}$ ), a $\mathrm{GABA}_{\mathrm{A}}$ receptor agonist, never excited control or DA-depleted MSNs recorded in cell-attached configuration $(n=$ 8) (Fig. 5D). Therefore, in DA-depleted striatum $\mathrm{GABA}_{\mathrm{A}}$ PSCs have the same effect on membrane potential of MSNs as in control striatum. Specifically, GABA depolarizes MSNs by $16-17 \mathrm{mV}$ from $V_{\text {rest }}$ (Fig. $5 E$ ), without evoking $\mathrm{Na}^{+}$spikes, as the threshold potential for spikes was $\sim 25$ $\mathrm{mV}$ more depolarized than $E_{\mathrm{GABA}}$.

\section{GABA oscillations of DA-depleted MSNs are not mediated by cholinergic signaling}

Several mechanisms could lead to the novel pattern of GABAergic oscillations observed, including changes in (1) activity of cholinergic interneurons, (2) presynaptic inhibition of GABA release by muscarinic receptors, (3) MSN-MSN recurrent collateral activity, or (4) activity of GABAergic interneurons, which would in turn generate GABA oscillations in MSNs. Interestingly, acetylcholine released by TANs excites GABA interneurons via nicotinic receptors (nAChRs) (Koós and Tepper, 2002), and in a primate Parkinson's disease model, TANs were said to shift to a bursting and oscillatory mode of activity (Raz et al., 1996). We performed the following pharmacological experiments in isolated striatum to avoid activation of structures afferent to striatum. Although nic- 
A1

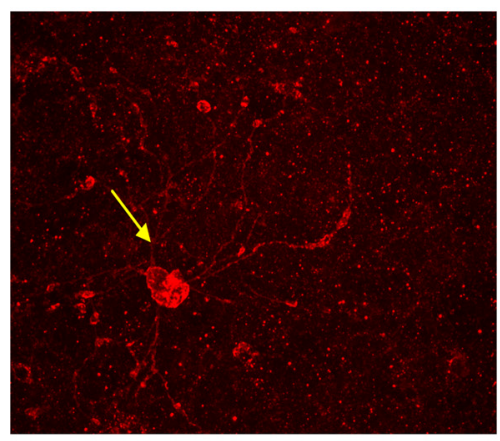

B1

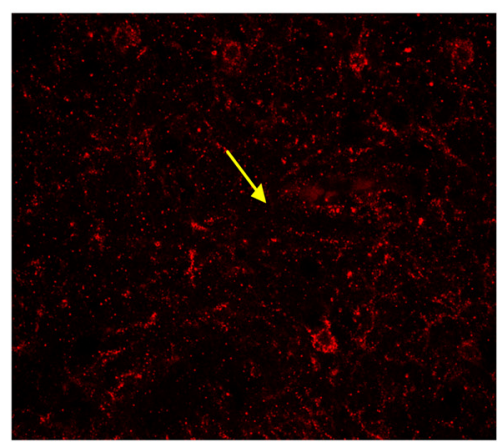

$20 \mu \mathrm{M}$
Biocytin
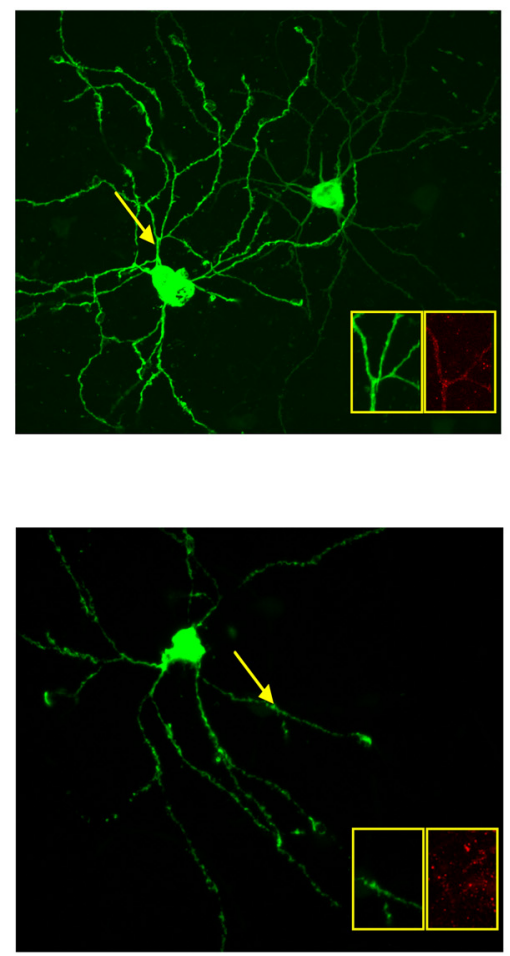

2

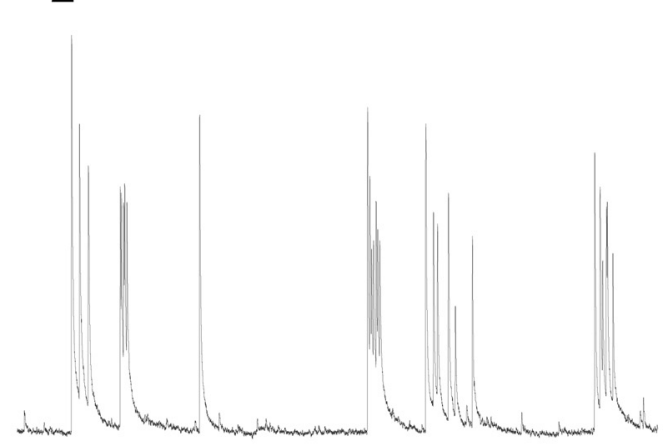

2 $1 \mathrm{~s}$ $100 \mathrm{pA}$

Figure 4. Oscillatory pattern recorded from MSNs positive $(\boldsymbol{A})$ or negative $(\boldsymbol{B})$ for $\mathrm{D}_{1}$ dopamine receptor expression. Confocal microphotographs (z-projections) of DA-depleted slices, double labeled for $D_{1}$ receptor (red) and biocytin (green) $(\boldsymbol{A} \mathbf{1}, \boldsymbol{B} \mathbf{1})$. The boxes contain enlarged portions of dendritic arbors to show the presence $(\boldsymbol{A})$ or the absence $(\boldsymbol{B})$ of colabeling. In $\boldsymbol{A} \mathbf{1}$, the recorded $\mathrm{MSN}$ is on the left. The MSN on the right was indirectly filled with biocytin, likely because of gap junction connections with the recorded MSN. Both recorded neurons in $\boldsymbol{A}$ and $\boldsymbol{B}$ generated the oscillatory pattern of $\mathrm{GABA}_{\mathrm{A}} \mathrm{SPSCS}(\boldsymbol{A} \mathbf{2}, \boldsymbol{B} \mathbf{2})$.

otine $(10-30 \mu \mathrm{M})$ increased the mean current density of GABA sPSCs 13-fold (from $1655 \pm 44$ to $20,941 \pm 1052 \mathrm{nA} \cdot \mathrm{ms} ; n=7$; $p<0.005$ ) (data not shown) in DA-depleted oscillating MSNs, the specific nicotinic antagonist mecamylamine $(3-10 \mu \mathrm{M})$ altered neither their mean current density (from $2508 \pm 862$ to $1975 \pm 985 \mathrm{nA} \cdot \mathrm{ms} ; n=6 ; p=0.13$ ) nor their oscillatory pattern (Fig. 6A). Alternately, acetylcholine released by TANs could affect GABA interneurons via muscarinic receptors (mAChRs). Muscarine $(10 \mu \mathrm{M})$ did not significantly affect the current density

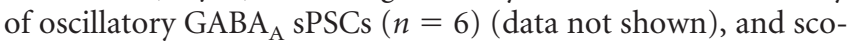
polamine $(10 \mu \mathrm{M})$, a broad spectrum muscarinic antagonist, also did not affect their mean current density (from $1894 \pm 300$ to $1497 \pm 400 \mathrm{nA} \cdot \mathrm{ms} ; n=5 ; p=0.21$ ) or their oscillatory pattern (Fig. 6A).

To further investigate a presynaptic modulation by muscarinic receptors of GABA release (Koós and Tepper, 2002), we determined the effects of carbachol on miniature $\mathrm{GABA}_{\mathrm{A}}$ PSCs. Carbachol $(30 \mu \mathrm{M})$ significantly decreased this frequency by $33 \%$ in control striatum (from $1.5 \pm 0.2$ to $1.0 \pm 0.1 \mathrm{~Hz} ; p<0.01 ; n=$ 9 cells), an effect that was totally reversed by scopolamine (10 $\mu \mathrm{M})$ (from $1.0 \pm 0.1$ to $1.9 \pm 0.2 \mathrm{~Hz} ; n=9$ cells) (supplemental Fig. $1 A$, available at www.jneurosci.org as supplemental material). In DA-depleted striatum, carbachol decreased the frequency of miniature $\mathrm{GABA}_{\mathrm{A}}$ events by $18 \%$ (from $2.2 \pm 0.5$ to $1.8 \pm 0.5 \mathrm{~Hz}$; $p<0.05 ; n=9$ cells), an effect that was completely reversed by scopolamine (from $1.8 \pm 0.5$ to $2.2 \pm 0.6 \mathrm{~Hz} ; n=9$ cells). The effects of carbachol on miniature $\mathrm{GABA}_{\mathrm{A}}$ currents was not statistically different between control and DA-depleted striatum ( $p=$ 0.12 ) (supplemental Fig. $1 B$, available at www.jneurosci.org as supplemental material).
Finally, cell-attached recordings of identified TANs confirmed that DA-depletion did not affect their tonic pattern of activity recorded in vitro (mean control frequency, $2.7 \pm 1.1 \mathrm{~Hz}$; $n=9$; mean DA-depleted frequency, $4.0 \pm 1.4 \mathrm{~Hz} ; n=8 ; p=0.4$ ) nor their basic characteristics (Fig. $6 \mathrm{~B}$ ). All of the above results strongly suggest that the oscillatory pattern of $\mathrm{GABA}_{\mathrm{A}} \mathrm{sPSCs}$ is independent of TAN activity.

\section{LTS GABA interneurons show bursting activity in DA-depleted slices}

Because all MSNs recorded in cell-attached or whole-cell configuration were silent in both control and DA-depleted striatum (Fig. 5D) and the strength of MSN-MSN connections dramatically reduced in DA-depleted conditions (Taverna et al., 2008), the synchronization of $\mathrm{GABA}_{\mathrm{A}}$ currents observed here likely resulted from a direct effect of chronic dopamine depletion on the activity of GABAergic interneurons. As these interneurons are rare and difficult to target with single-cell electrophysiological techniques, particularly in lesioned tissue, we first performed extracellular recordings with conventional extracellular electrodes or multiarray electrodes (see Materials and Methods) to test for the presence of oscillatory activities under control or lesioned conditions. In control BGS ( $n=3$ slices) and control isolated striatum ( $n=12$ slices), we never recorded oscillatory activities. Neurons were either silent or showed single-spike activity. In contrast, in DA-depleted BGS $(n=2)$ and isolated striatum $(n=$ 11 ), oscillatory activity was observed together with single-spike activity (data not shown).

Cell-attached recordings combined with subsequent wholecell recording of spike responses to intracellular current steps and 
A $i_{\text {NMDA }}$

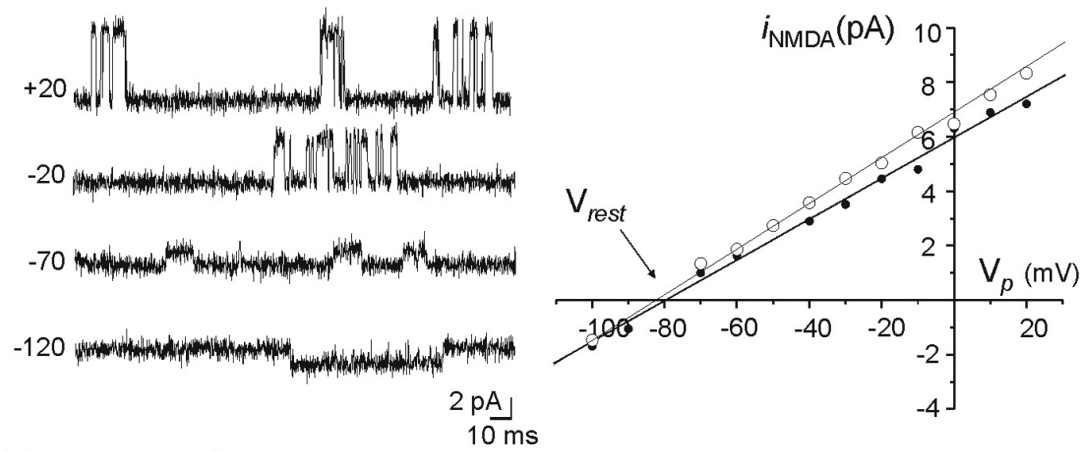

B

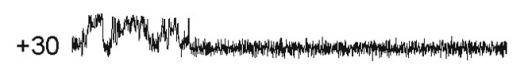

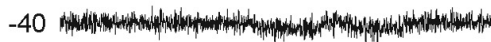
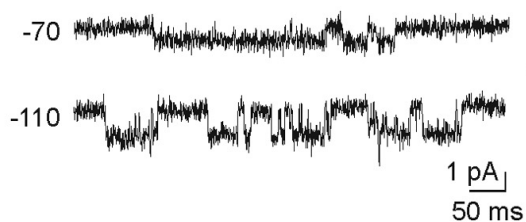

C

Control
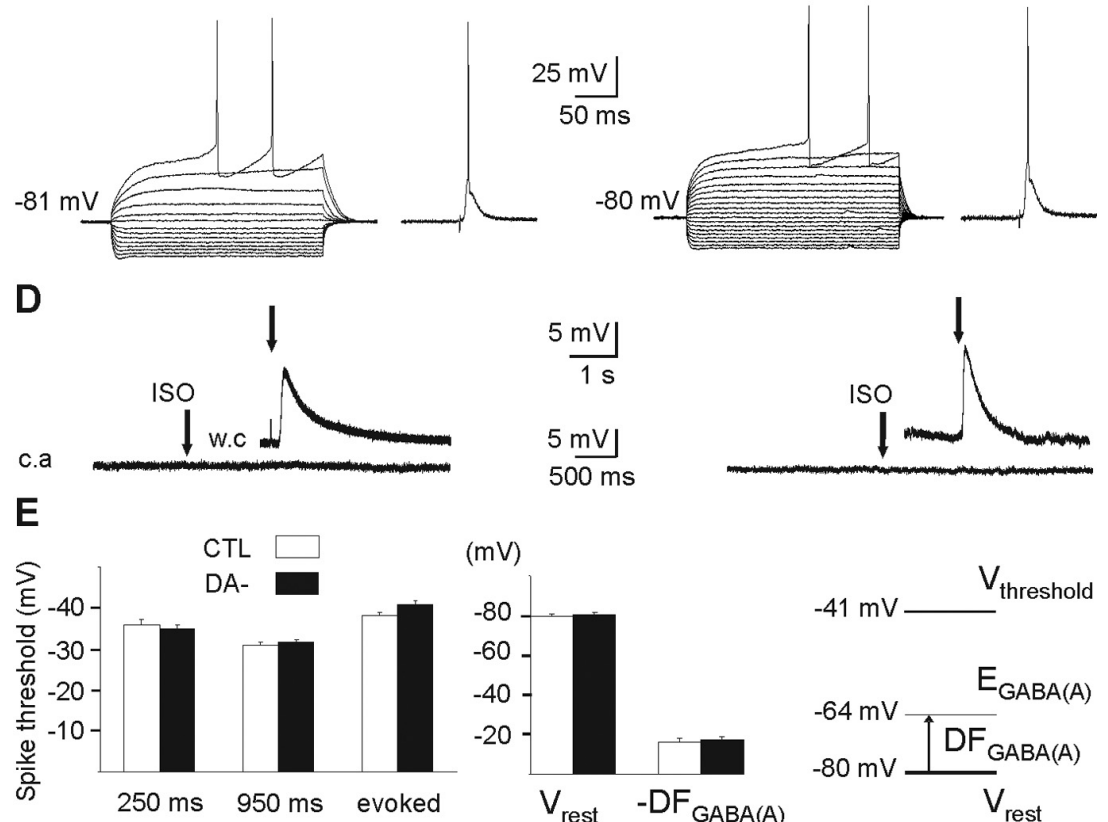

$500 \mathrm{~ms}$
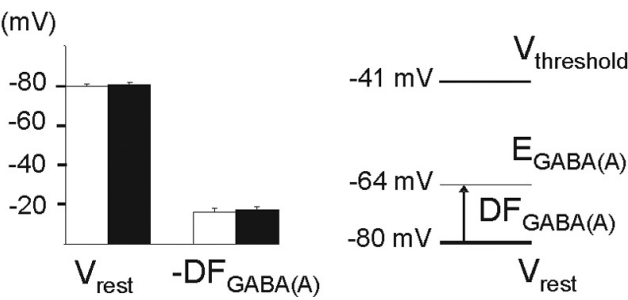

Figure 5. $\quad V_{\text {rest }}, E_{G A B A}$, and $V_{\text {threshold }}$ in MSNs of control and DA-depleted striatum. $\boldsymbol{A}$, Cell-attached recordings of unitary NMDA currents at the indicated holding potentials (in millivolts) from a DA-depleted MSN (left) and $i_{\text {NMDA }}-V$ relationship in control $(\bigcirc)$ and DA-depleted $(\bigcirc)$ MSNs (right). $\boldsymbol{B}$, Cell-attached recordings of unitary $G_{A B A_{A}}$ currents at the indicated holding potentials (in millivolts) from a DA-depleted MSN (left) and $i_{\mathrm{GABA}_{A}}-V$ relationship in control $(\bigcirc)$ and DA-depleted $(\bigcirc)$ MSNs (right). The illustrated traces and corresponding $I-V$ curves for NMDA and GABA currents are from the same cells. C, Whole-cell current-clamp recordings of the responses of control (left) and DA-depleted (right) MSNs to intracellular hyperpolarizing and depolarizing steps and to cortical stimulation. $\boldsymbol{D}$, Absence of excitatory responses of cell-attached (c.a) recorded MSNs to local pressure application of isoguvacine $(100 \mu \mathrm{m}), \mathrm{a} \mathrm{GABA}_{\mathrm{A}}$ receptor agonist, in control (left) and DA-depleted (right) state. The insets show the depolarizing effect of isoguvacine $(100 \mu \mathrm{m})$ after rupture of the membrane [whole-cell recording (w.c)] to check the efficacy of pressure application. $\boldsymbol{E}$, Spike threshold was not significantly different in control and DA-depleted MSNs when tested in response to 250 or $950 \mathrm{~ms}$ intracellular currents pulses or evoked by cortical stimulation. Resting membrane potential $\left(V_{\text {rest }}\right)_{\text {, }}$ driving force for chloride ions $\left(\mathrm{DF}_{\mathrm{GABA}_{A}}\right)$ or reversal potential for $\mathrm{GABA}_{\mathrm{A}}$ current, and threshold potential for spikes $\left(V_{\text {threshold }}\right)$ were not significantly different in control and DA-depleted MSNs. Error bars indicate SEM. See Results for additional explanations. post hoc morphological examination of the recorded neurons showed that FS (Fig. 7A, left) and LTS (Fig. 7B, left) interneurons were silent or tonically active in control striatum. FS mean frequency of activity was $10.1 \pm 0.2 \mathrm{~Hz}(n=2$ of 5$)$ and LTS mean frequency was $8.8 \pm 1.1 \mathrm{~Hz}$ with rare trains at $\sim 20 \mathrm{~Hz}(n=3$ of 5$)$. In lesioned conditions, FS interneurons still discharged in single-spike mode $(7.4 \pm 2.5$ $\mathrm{Hz} ; n=6$ of 18 ) or stayed silent (Fig. 7, compare $B 3, B 4$, with $A 3, A 4$ ). In contrast, some LTS interneurons shifted to an oscillatory activity consisting of long bursts of spikes at a mean frequency of $71 \pm 30 \mathrm{~Hz}$ separated by silent periods of $3.9 \pm 1.6 \mathrm{~s}$ $(n=3$ of 5$)$. This LTS bursting activity was insensitive to the presence of blockers of glutamatergic transmission (Fig. 7B4), suggesting that it is not generated by corticostriatal activity. The remaining LTS displayed a tonic activity at $9.7 \pm 1.7 \mathrm{~Hz}$ ( $n=2$ of 5 ). Interestingly, the intraburst frequency of spikes generated by LTS interneurons in DA-depleted condition was close to the intraburst frequency of $\mathrm{GABA}_{\mathrm{A}}$ currents recorded in DA-depleted MSNs (see results above).

\section{Discussion}

Our results show that chronic dopamine depletion profoundly alters the pattern of $\mathrm{GABA}_{\mathrm{A}}$ activity, shifting the currents in one-half of the MSN population from a continuous tonic pattern of sPSCs to an oscillatory pattern consisting of giant single sPSCs, and/or bursts of sPSCs at a gamma frequency $(\sim 60 \mathrm{~Hz})$. Using, for the first time, single-channel recordings of NMDA and GABA receptors in the striatum, we show that these alterations are not associated with shifts of the reversal potential for GABA or the resting membrane potential, suggesting that they are not attributable to excitatory actions of GABA. The threshold for spike generation is also unaltered by chronic dopamine depletion and cholinergic signals are not involved. We propose that the fundamental effect of the chronic removal of dopaminergic control on GABAergic circuits of the striatum is the shift of activity of GABAergic LTS interneurons from single-spike to bursting pattern and the increase in efficacy of GABAergic synaptic transmission. This leads in turn to the generation of repetitive giant bursts of GABA currents by one-half of the MSN population.

In both sagittal striatal slices from control mice (the present experiment) and coronal slices from control rats (Centonze et al., 2004; Cummings et al., 2008), MSNs generate a tonic pattern of low amplitude 
$\mathrm{GABA}_{\mathrm{A}}$ currents (5-30 pA) at low frequency $(\sim 2.5-4 \mathrm{~Hz})$. DA depletion shifted this pattern to an oscillatory one in $\mathrm{D}_{1}$-positive as well as $\mathrm{D}_{1}$-negative MSNs, suggesting that the effect of DA depletion on the pattern of $\mathrm{GABA}_{\mathrm{A}}$ currents did not target a particular subpopulation of MSNs. The $55 \%$ of the MSNs that generated the tonic $\mathrm{GABA}_{\mathrm{A}}$ pattern rather than the oscillatory one may be explained by their low degree of connectivity to GABA interneurons in the slice, or to a true difference in GABAergic innervation between the two MSNs groups.

What is the origin of the shift to the oscillatory pattern? Cholinergic interneurons, the TANs, were good candidates, as they are supposed to oscillate in the chronic absence of dopamine (Raz et al., 1996). However, in our experimental conditions, nicotinic and muscarinic blockers did not affect the oscillatory pattern, and identified TANs displayed the same tonic pattern of activity in the presence or absence of dopaminergic innervation. In simultaneous whole-cell recording of pairs of FS interneurons and MSNs, acetylcholine attenuates GABAergic inhibition of MSNs through activation of presynaptic muscarinic receptors located on GABA axon terminals (Marchi et al., 1990; Koós and Tepper, 2002). We showed that dopamine depletion of the striatum does not affect this process, suggesting that chronic alterations of presynaptic inhibition of GABA release by muscarinic receptors is also unlikely to be responsible for the generation of oscillatory GABA sPSCs. Concerning presynaptic control of GABA release by dopamine receptors, recordings of spontaneous $\mathrm{GABA}_{\mathrm{A}}$ currents from $\mathrm{D}_{2}$ receptor knock-out mice revealed a loss of the inhibitory effect of the $\mathrm{D}_{2}$ agonist quinpirole (Centonze et al., 2004).

Therefore, dopamine deprivation may produce a dual action: alteration of the basic activity pattern of a subpopulation of GABA interneurons, and decrease of presynaptic inhibition of GABA release leading to repetitive giant $\mathrm{GABA}_{\mathrm{A}}$ currents. Approximately 4-27 FS interneurons project to each MSN (Koós and Tepper, 1999), and each FS cell establishes a mean of six release sites per MSN (up to 18) that are often organized in clusters of synaptic contacts on the soma or proximal dendrites (Kita et al., 1990). This distribution and the proximity to the cell body enable an efficient inhibitory control of MSNs. In contrast, MSN-MSN recurrent synapses are on distal dendrites with only a small number of release sites (average of three) (Wilson and Groves, 1980). These may thus be less prone to generation of giant sPSCs. Despite the relatively high degree of convergence (each MSN receives $\sim 500$ synapses from other MSNs) (Czubayko and Plenz, 2002; Guzmán et al., 2003; Koós et al., 2004), this recurrent system is unlikely to mediate the generation of giant GABAergic currents, because MSNs were silent in BGS and isolated striatum and their strength mostly de-
A GABA $_{A}$ PSCs in MSNs

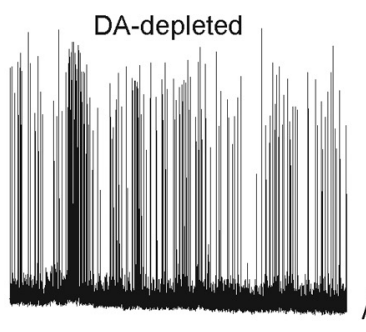

//

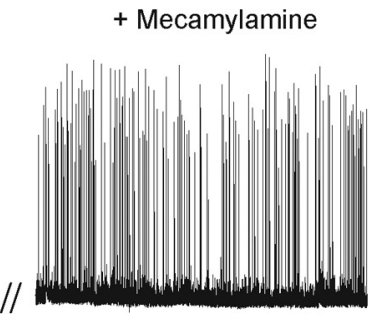

+ Scopolamine
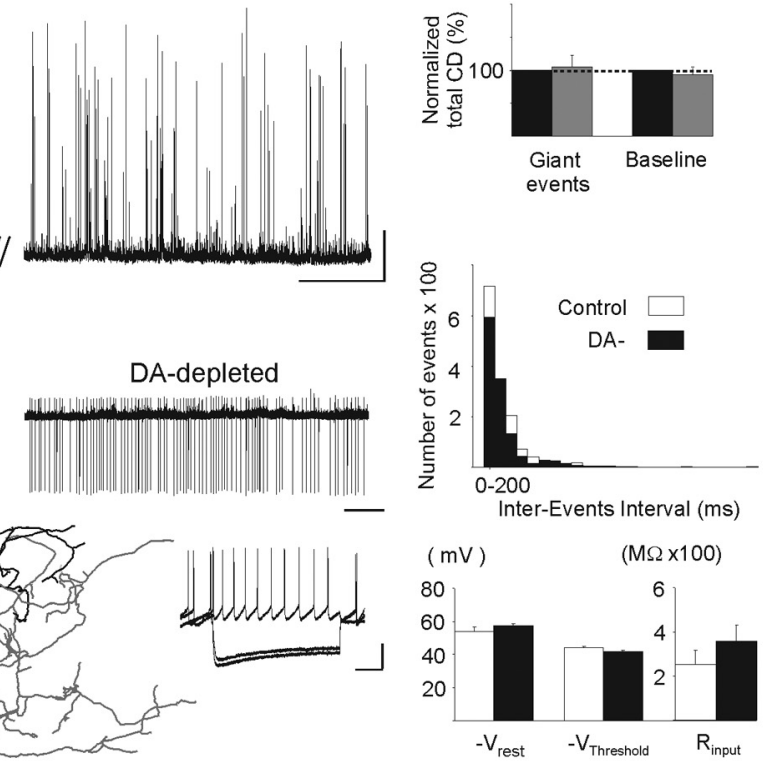

Figure 6. Effect of cholinergic antagonists on the oscillatory pattern of GABA $s P S C s$ and TAN activity in DA-depleted state. $\boldsymbol{A}$, Lack of effect of bath application of mecamylamine (5 $\mu \mathrm{m}$ ) (top traces) or scopolamine (10 $\mu \mathrm{m})$ (bottom traces) on the oscillatory

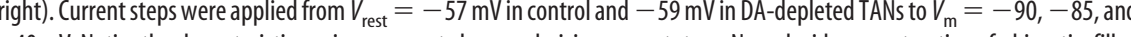
TAN with its dendritic tree in black and its collateralized axon in gray. Scale bar, $50 \mu \mathrm{m}$. DA depletion did not affect TANs spontaneous pattern of activity (see the distribution of interevents intervals) nor their mean values of $V_{\text {rest }}(-54.0 \pm 2.7$ vs $-57.2 \pm 1.2 \mathrm{mV} ; n=7$ and $11 ; p=0.4), V_{\text {threshold }}(-44.2 \pm 0.3$ vs $-41.7 \pm 0.9 \mathrm{mV} ; n=7$ and $11 ; p=0.1)$ and input resistance $\left(R_{\text {input }}\right)(255 \pm 63$ vs $357 \pm 74 \mathrm{M} \Omega ; p=0.4$ ) (right diagrams). Calibration: $\boldsymbol{A}, 25 \mathrm{~s}, 100 \mathrm{pA} ; \boldsymbol{B}, 5 \mathrm{~s}$ (top) and $200 \mathrm{~ms}, 25$ $\mathrm{mV}$ (bottom steps). Error bars indicate SEM.

creased in the chronic absence of dopamine (Taverna et al., 2008). FS interneurons are also unlikely to mediate bursts of GABAergic currents because DA depletion did not affect their single-spike firing pattern. In contrast, we showed for the first time that identified LTS interneurons spontaneously discharge with a striking bursting pattern in the absence of dopamine, a type of activity not recorded under control conditions. Moreover, the intraburst frequency of LTS spikes was close to that of GABAergic currents recorded in MSNs.

Our single GABA and NMDA channel recordings (Tyzio et al., 2003) indicate for the first time a value for the reversal potential of GABA current $\left(E_{\mathrm{GABA}}=-63.0 \pm 2.9 \mathrm{mV}\right)$ of DA-depleted MSNs. We also showed that the resting membrane potential $\left(V_{\text {rest }}=-80 \mathrm{mV}\right.$ ) and $E_{\mathrm{GABA}}$ of MSNs are not affected by dopamine depletion. All these values are based on the assumption that the NMDA current reverses at $0 \mathrm{mV}$ in MSNs. Although an error of $\sim 5 \mathrm{mV}$ may exist (Tyzio et al., 2003), the comparison of $V_{\text {rest }}$ 


\section{A FS}

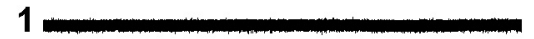

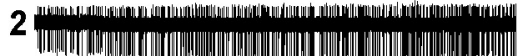
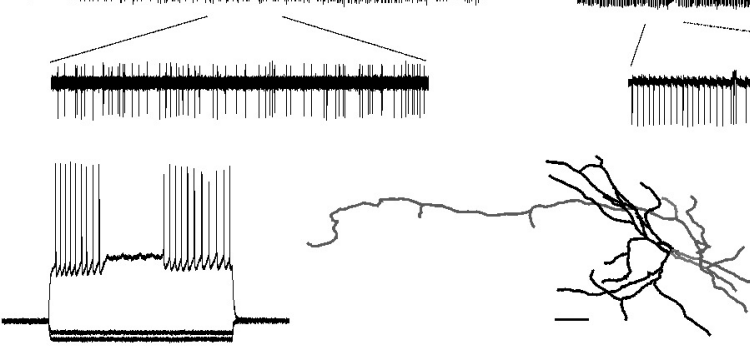

\section{B LTS}

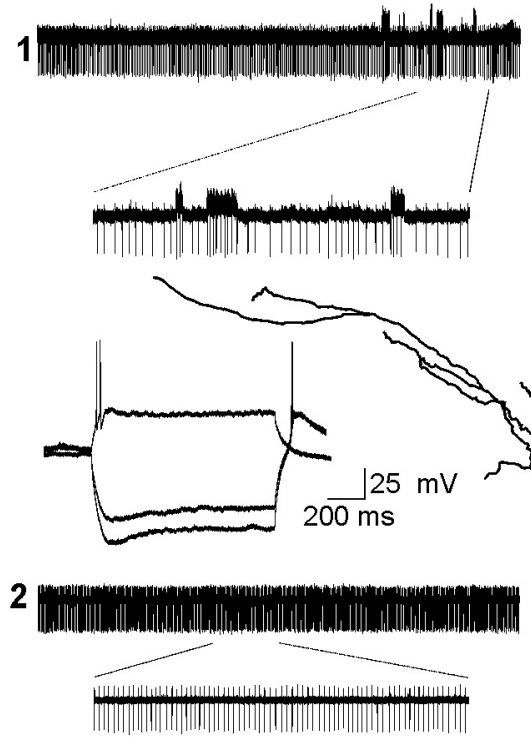

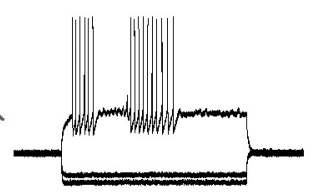

3

4

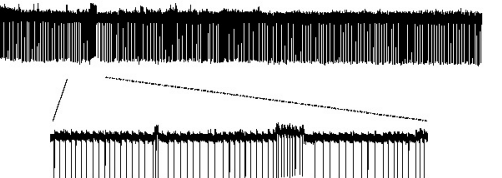

3

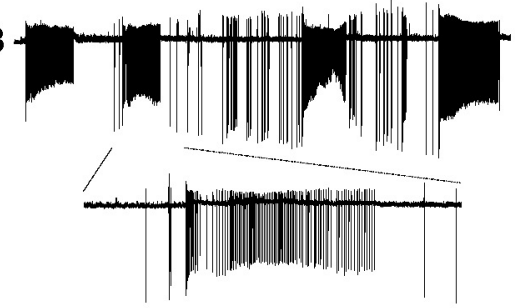

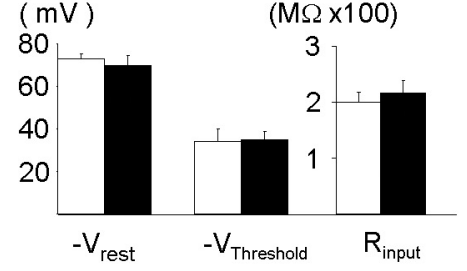
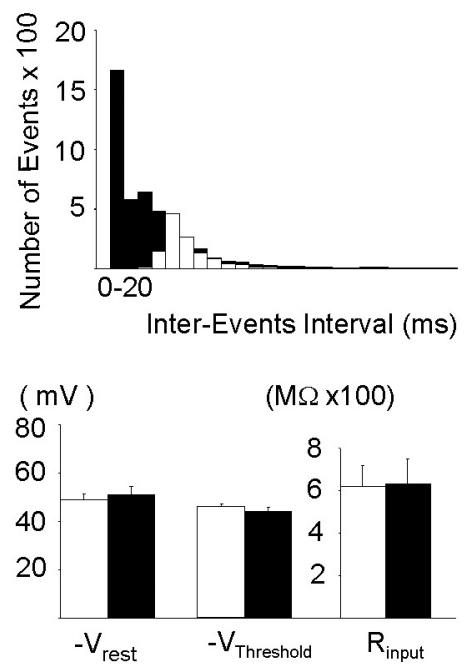

Figure 7. Spontaneous activity of GABAergic FS and LTS interneurons in control and DA-depleted striatum. $\boldsymbol{A}$, Activity of FS interneurons recorded in cell-attached configuration in control (1, 2) and DA-depleted (3,4) striatum. Sixty percent of FS were silent in control striatum (1) and 67\% in DA-depleted one (3). The remaining FS displayed single-spike regular activity with rare trains of spikes (4). The bottom traces in 2 and 4 are expanded traces of the top ones as indicated. Note the typical FS firing in response to depolarizing steps (bottom traces) recorded in control from neuron 2 and in DA-depleted striatum from neuron 4. Current steps were applied from $V_{\text {rest }}=-74.8 \mathrm{mV}$ to $V_{\mathrm{m}}=-82,-78$, and $-29 \mathrm{mV}$ in control and from $V_{\text {rest }}=-78 \mathrm{mV}$ to $-90,-85$, and -37 $\mathrm{mV}$ in DA-depleted FS neurons. Neurolucida reconstruction of the biocytin-filled FS interneuron 2 show the aspiny dendrites (black) and the collateralized axon (gray). The right diagrams show that the interevent intervals distribution and the mean value of $V_{\text {rest }}(-73.0 \pm 2.3 \mathrm{vs}-69.6 \pm 5.0 \mathrm{mV} ; n=5$ and $6 ; p=0.6), V_{\text {threshold }}(-34.0 \pm 5.8 \mathrm{vs}-34.8 \pm 3.7 \mathrm{mV} ; n=5$ and $7 ; p=0.9)$, and input resistance $\left(R_{\text {input }}\right)(199 \pm 18$ vs $217 \pm 21 \mathrm{M} \Omega ; n=5$ and $7 ; p=0.6)$ were unchanged by DA depletion. $\boldsymbol{B}$, LTS interneurons switch from a tonic control activity to a bursting one in DA-depleted condition. Two examples of control $(1,2)$ and DA-depleted $(3,4)$ LTS activities are shown. LTS in 4 was recorded in the continuous presence of the glutamatergic antagonists APV $(10$ $\mu \mathrm{M})$ and $\mathrm{CNQX}(40 \mu \mathrm{M})$. Note the typical rebound after hyperpolarizing steps giving rise to spikes and the low-threshold $\mathrm{Ca}^{2+}$ spike in response to depolarizing steps (bottom traces) recorded in control from neuron 1 and in DA-depleted striatum from neuron 3. Current steps were applied from $V_{\mathrm{m}}=-70 \mathrm{mV}$ to $V_{\mathrm{m}}=-130,-115$, and $-43 \mathrm{mV}$ in control and from $V_{\mathrm{m}}=-71 \mathrm{mV}$ to $-120,-115,-55$, and -47 in DA-depleted LTS neurons. Neurolucida reconstruction of the biocytin-filled LTS interneuron 3 show the extended dendritic field and the aspiny dendrites (the axon was not visible). The right diagrams show that the interevent intervals distribution was shifted to the left. The mean values of $V_{\text {rest }}(-48.7 \pm 2.5 \mathrm{vs}-51.0 \pm 3.1 \mathrm{mV} ; n=5$ and $6 ; p=0.6)$, $V_{\text {threshold }}(-46.5 \pm 0.7 \mathrm{vs}-42.4 \pm 1.4 \mathrm{mV} ; n=5$ and $5 ; p=0.06)$, and input resistance $\left(R_{\text {input }}\right)(622 \pm 97 \mathrm{vs} 630 \pm 118 \mathrm{M} \Omega ; n=5$ and $6 ; p=0.9)$ were unchanged by $D A$ depletion. Calibrations are identical for all cell-attached recordings ( $5 \mathrm{~s}$ for main traces and $1 \mathrm{~s}$ for enlarged ones) and for all whole-cell recordings ( $25 \mathrm{mV}, 200 \mathrm{~ms}$ ). Scale bar for neurons, $50 \mu \mathrm{m}$. Error bars indicate SEM.

and $E_{\mathrm{GABA}}$ obtained with the same methods in control and DAdepleted MSNs confirms the validity of our conclusions. Another noninvasive method to determine $V_{\text {rest }}$ consists in estimating the reversal potential for $\mathrm{K}^{+}$ions using cell-attached recordings with pipettes containing $145-155 \mathrm{~mm} \mathrm{~K}^{+}$ions. With the symmetric $\mathrm{K}^{+}$gradient, the $\mathrm{K}^{+}$current through the membrane patch reverses when the potential of the pipette is equal to the membrane potential $\left(V_{\text {rest }}\right)$ (Verheugen et al., 1999). This measure is based on the approximation of the internal $\mathrm{K}^{+}$concentration. Interest- ingly, both protocols (single NMDA current or equimolar $\mathrm{K}^{+}$) gave similar results $(-80 /-81 \mathrm{mV})$ in control MSNs (Ade et al., 2008). These values are also close to those obtained with gramicidin perforated patch that leaves the internal chloride concentration intact ( -81 and $-64 \pm 4 \mathrm{mV}$, respectively) (Bracci and Panzeri, 2006) [for more depolarized values in organotypic cultures, see also Gustafson et al. (2006)]. Our determination of spike threshold in control and DA-depleted MSNs in whole-cell recordings and KGlu electrodes is close to that previously identi- 
fied under the same conditions [ $-36 \mathrm{mV}$ (Taverna et al., 2007); $-38 \mathrm{mV}$ (Fino et al., 2007)]. Therefore, GABAergic synapses depolarize MSNs from $V_{\text {rest }}$ (Misgeld et al., 1982; Koós and Tepper, 1999) but do not trigger action potentials and hence can exert inhibitory actions (Plenz and Aertsen, 1996). The membrane potential of MSNs in vivo, under urethane or sodium pentobarbital anesthesia, oscillates between down and up states, the latter being generated by glutamatergic afferents (Wilson and Kawaguchi, 1996; Mahon et al., 2001; Tseng et al., 2001). Spontaneous or evoked activation of $\mathrm{GABA}_{\mathrm{A}}$ receptors depolarize the MSN membrane in vivo during the down state (Mercuri et al., 1991) and hyperpolarize it during the up state (Plenz and Kitai, 1998), suggesting that GABA exerts an inhibitory action on MSN activity.

We propose that the fundamental feature of the dopaminedeprived isolated striatum is a shift from a continuous tonic GABA pattern to one that oscillates between repetitive giant $\mathrm{sP}$ SCs and silent episodes. This results from alterations of the firing properties of a subpopulation of GABA interneurons that shifts from low-frequency tonic to high-frequency oscillatory activity. The shift in the $\mathrm{GABA}_{\mathrm{A}}$ pattern may profoundly alter the response of one-half the MSNs to cortical inputs in vivo, thus destabilizing striatal function. During down states, GABA-induced depolarization decreases the impact of the hyperpolarizationactivated inward rectifier $\mathrm{K}^{+}$current that prevents MSNs from excitation-induced rapid firing (Surmeier and Kitai, 1993; Nicola et al., 2000). It will also drive the MSN membrane to a potential $(-65 \mathrm{mV})$ at which its input resistance and time constant are close to maximal (Wilson, 2007), which may facilitate glutamatergic inputs and lead to the generation of action potentials (Bracci and Panzeri, 2006). Along the same lines, blockade of spontaneous and tonic $\mathrm{GABA}_{\mathrm{A}}$ synaptic transmission decreased the cortically evoked excitation recorded from MSNs in the cellattached configuration (Ade et al., 2008). In contrast, during up states that are more frequent in DA-depleted striatum [MSNs spend a longer time in up states in chronically 6-hydroxydopamine-lesioned rats (Murer et al., 2002)], giant GABAergic currents should efficiently and transiently inhibit cortical inputs, preventing information transfer and integration.

\section{References}

Ade KK, Janssen MJ, Ortinski PI, Vicini S (2008) Differential tonic GABA conductances in striatal medium spiny neurons. J Neurosci 28:1185-1197.

Bennett BD, Bolam JP (1994) Localisation of parvalbuminimmunoreactive structures in primate caudate-putamen. J Comp Neurol 347:340-356.

Beurrier C, Ben-Ari Y, Hammond C (2006) Preservation of the direct and indirect pathways in an in vitro preparation of the mouse basal ganglia. Neuroscience 140:77-86.

Bracci E, Panzeri S (2006) Excitatory GABAergic effects in striatal projection neurons. J Neurophysiol 95:1285-1290.

Bracci E, Centonze D, Bernardi G, Calabresi P (2002) Dopamine excites fast-spiking interneurons in the striatum. J Neurophysiol 87:2190-2194.

Calabresi P, Picconi B, Tozzi A, Di Filippo M (2007) Dopamine-mediated regulation of corticostriatal synaptic plasticity. Trends Neurosci 30:211-219.

Centonze D, Bracci E, Pisani A, Gubellini P, Bernardi G, Calabresi P (2002) Activation of dopamine D1-like receptors excites LTS interneurons of the striatum. Eur J Neurosci 15:2049-2052.

Centonze D, Grande C, Usiello A, Gubellini P, Erbs E, Martin AB, Pisani A, Tognazzi N, Bernardi G, Moratalla R, Borrelli E, Calabresi P (2003) Receptor subtypes involved in the presynaptic and postsynaptic actions of dopamine on striatal interneurons. J Neurosci 23:6245-6254.

Centonze D, Gubellini P, Usiello A, Rossi S, Tscherter A, Bracci E, Erbs E, Tognazzi N, Bernardi G, Pisani A, Calabresi P, Borrelli E (2004) Differ- ential contribution of dopamine D2S and D2L receptors in the modulation of glutamate and GABA transmission in the striatum. Neuroscience 129:157-166.

Clark BA, Farrant M, Cull-Candy SG (1997) A direct comparison of the single-channel properties of synaptic and extrasynaptic NMDA receptors. J Neurosci 17:107-116.

Cohen I, Navarro V, Clemenceau S, Baulac M, Miles R (2002) On the origin of interictal activity in human temporal lobe epilepsy in vitro. Science 298:1418-1421.

Cossart R, Hirsch JC, Cannon RC, Dinoncourt C, Wheal HV, Ben-Ari Y, Esclapez M, Bernard C (2000) Distribution of spontaneous currents along the somato-dendritic axis of rat hippocampal CA1 pyramidal neurons. Neuroscience 99:593-603.

Cummings DM, Yamazaki I, Cepeda C, Paul DL, Levine MS (2008) Neuronal coupling via connexin 36 contributes to spontaneous synaptic currents of striatal medium-sized spiny neurons. J Neurosci Res 86:2147-2158.

Czubayko U, Plenz D (2002) Fast synaptic transmission between striatal spiny projection neurons. Proc Natl Acad Sci U S A 99:15764-15769.

Fino E, Glowinski J, Venance L (2007) Effects of acute dopamine depletion on the electrophysiological properties of striatal neurons. Neurosci Res 58:305-316.

Guigoni C, Doudnikoff E, Li Q, Bloch B, Bezard E (2007) Altered D(1) dopamine receptor trafficking in parkinsonian and dyskinetic nonhuman primates. Neurobiol Dis 26:452-463.

Gustafson N, Gireesh-Dharmaraj E, Czubayko U, Blackwell KT, Plenz D (2006) A comparative voltage and current-clamp analysis of feedback and feedforward synaptic transmission in the striatal microcircuit in vitro. J Neurophysiol 95:737-752.

Guzmán JN, Hernández A, Galarraga E, Tapia D, Laville A, Vergara R, Aceves J, Bargas J (2003) Dopaminergic modulation of axon collaterals interconnecting spiny neurons of the rat striatum. J Neurosci 23:8931-8940.

Heuschkel MO, Fejtl M, Raggenbass M, Bertrand D, Renaud P (2002) A three-dimensional multi-electrode array for multi-site stimulation and recording in acute brain slices. J Neurosci Methods 114:135-148.

Iancu R, Mohapel P, Brundin P, Paul G (2005) Behavioral characterization of a unilateral 6-OHDA-lesion model of Parkinson's disease in mice. Behav Brain Res 162:1-10.

Kawaguchi Y (1993) Physiological, morphological, and histochemical characterization of three classes of interneurons in rat neostriatum. J Neurosci 13:4908-4923.

Kita H, Kosaka T, Heizmann CW (1990) Parvalbumin-immunoreactive neurons in the rat neostriatum: a light and electron microscopic study. Brain Res 536:1-15.

Koós T, Tepper JM (1999) Inhibitory control of neostriatal projection neurons by GABAergic interneurons. Nat Neurosci 2:467-472.

Koós T, Tepper JM (2002) Dual cholinergic control of fast-spiking interneurons in the neostriatum. J Neurosci 22:529-535.

Koós T, Tepper JM, Wilson CJ (2004) Comparison of IPSCs evoked by spiny and fast-spiking neurons in the neostriatum. J Neurosci 24:7916-7922.

Kubota Y, Kawaguchi Y (2000) Dependence of GABAergic synaptic areas on the interneuron type and target size. J Neurosci 20:375-386.

Levey AI, Hersch SM, Rye DB, Sunahara RK, Niznik HB, Kitt CA, Price DL, Maggio R, Brann MR, Ciliax BJ (1993) Localization of D1 and D2 dopamine receptors in brain with subtype-specific antibodies. Proc Natl Acad Sci U S A 90:8861-8865.

Mahon S, Deniau JM, Charpier S (2001) Relationship between EEG potentials and intracellular activity of striatal and cortico-striatal neurons: an in vivo study under different anesthetics. Cereb Cortex 11:360-373.

Mallet N, Le Moine C, Charpier S, Gonon F (2005) Feedforward inhibition of projection neurons by fast-spiking GABA interneurons in the rat striatum in vivo. J Neurosci 25:3857-3869.

Marchi M, Sanguineti P, Raiteri M (1990) Muscarinic receptors mediate direct inhibition of GABA release from rat striatal nerve terminals. Neurosci Lett 116:347-351.

Mercuri NB, Calabresi P, Stefani A, Stratta F, Bernardi G (1991) GABA depolarizes neurons in the rat striatum: an in vivo study. Synapse 8:38-40.

Misgeld U, Wagner A, Ohno T (1982) Depolarizing IPSPs and depolarization by GABA of rat neostriatum cells in vitro. Exp Brain Res 45:108-114. Momiyama T (2002) Dopamine receptors and calcium channels regulating 
striatal inhibitory synaptic transmission (in Japanese). Nippon Yakurigaku Zasshi 120:61P-63P.

Murer MG, Tseng KY, Kasanetz F, Belluscio M, Riquelme LA (2002) Brain oscillations, medium spiny neurons, and dopamine. Cell Mol Neurobiol 22:611-632.

Nadjar A, Brotchie JM, Guigoni C, Li Q, Zhou SB, Wang GJ, Ravenscroft P, Georges F, Crossman AR, Bezard E (2006) Phenotype of striatofugal medium spiny neurons in parkinsonian and dyskinetic nonhuman primates: a call for a reappraisal of the functional organization of the basal ganglia. J Neurosci 26:8653-8661.

Nicola SM, Surmeier J, Malenka RC (2000) Dopaminergic modulation of neuronal excitability in the striatum and nucleus accumbens. Annu Rev Neurosci 23:185-215.

Nowak L, Bregestovski P, Ascher P, Herbet A, Prochiantz A (1984) Magnesium gates glutamate-activated channels in mouse central neurones. Nature 307:462-465.

Plenz D, Aertsen A (1996) Neural dynamics in cortex-striatum co-cultures-II. Spatiotemporal characteristics of neuronal activity. Neuroscience 70:893-924.

Plenz D, Kitai ST (1998) Up and down states in striatal medium spiny neurons simultaneously recorded with spontaneous activity in fast-spiking interneurons studied in cortex-striatum-substantia nigra organotypic cultures. J Neurosci 18:266-283.

Raz A, Feingold A, Zelanskaya V, Vaadia E, Bergman H (1996) Neuronal synchronization of tonically active neurons in the striatum of normal and parkinsonian primates. J Neurophysiol 76:2083-2088.

Steidl EM, Neveu E, Bertrand D, Buisson B (2006) The adult rat hippocampal slice revisited with multi-electrode arrays. Brain Res 1096:70-84.

Sullivan MA, Chen H, Morikawa H (2008) Recurrent inhibitory network among striatal cholinergic interneurons. J Neurosci 28:8682-8690.

Surmeier DJ, Kitai ST (1993) D1 and D2 dopamine receptor modulation of sodium and potassium currents in rat neostriatal neurons. Prog Brain Res 99:309-324.

Taverna S, Canciani B, Pennartz CM (2007) Membrane properties and synaptic connectivity of fast-spiking interneurons in rat ventral striatum. Brain Res 1152:49-56.
Taverna S, Ilijic E, Surmeier DJ (2008) Recurrent collateral connections of striatal medium spiny neurons are disrupted in models of Parkinson's disease. J Neurosci 28:5504-5512.

Tepper JM, Bolam JP (2004) Functional diversity and specificity of neostriatal interneurons. Curr Opin Neurobiol 14:685-692.

Tepper JM, Wilson CJ, Koós T (2008) Feedforward and feedback inhibition in neostriatal GABAergic spiny neurons. Brain Res Rev 58:272-281.

Tseng KY, Kasanetz F, Kargieman L, Riquelme LA, Murer MG (2001) Cortical slow oscillatory activity is reflected in the membrane potential and spike trains of striatal neurons in rats with chronic nigrostriatal lesions. J Neurosci 21:6430-6439.

Tunstall MJ, Oorschot DE, Kean A, Wickens JR (2002) Inhibitory interactions between spiny projection neurons in the rat striatum. J Neurophysiol 88:1263-1269.

Tyzio R, Ivanov A, Bernard C, Holmes GL, Ben-Ari Y, Khazipov R (2003) Membrane potential of CA3 hippocampal pyramidal cells during postnatal development. J Neurophysiol 90:2964-2972.

Venance L, Glowinski J, Giaume C (2004) Electrical and chemical transmission between striatal GABAergic output neurones in rat brain slices. J Physiol 559:215-230.

Verheugen JA, Fricker D, Miles R (1999) Noninvasive measurements of the membrane potential and GABAergic action in hippocampal interneurons. J Neurosci 19:2546-2555.

Wilson CJ (2007) GABAergic inhibition in the neostriatum. Prog Brain Res 160:91-110.

Wilson CJ, Groves PM (1980) Fine structure and synaptic connections of the common spiny neuron of the rat neostriatum: a study employing intracellular inject of horseradish peroxidase. J Comp Neurol 194:599-615.

Wilson CJ, Kawaguchi Y (1996) The origins of two-state spontaneous membrane potential fluctuations of neostriatal spiny neurons. J Neurosci 16:2397-2410.

Zhou FM, Wilson CJ, Dani JA (2002) Cholinergic interneuron characteristics and nicotinic properties in the striatum. J Neurobiol 53:590605 . 